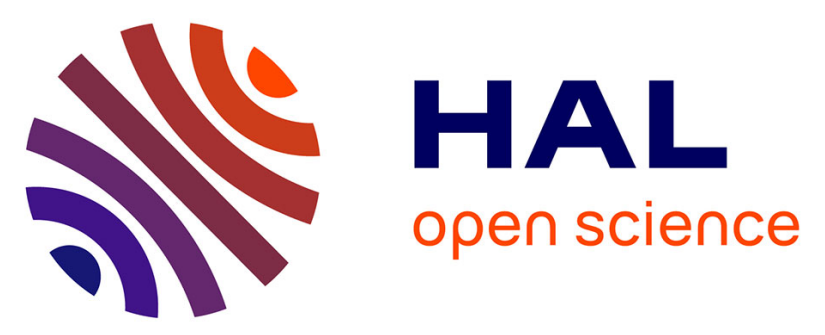

\title{
New Synthetic Routes towards Soluble and Dissymmetric Triphenodioxazine Dyes Designed for Dye-Sensitized Solar Cells
}

Yohann Nicolas, Fouzia Allama, Marc Lepeltier, Julien Massin, Frédéric Castet, Laurent Ducasse, Lionel Hirsch, Zahia Boubegtiten, Gediminas Jonusauskas, Céline Olivier, et al.

\section{To cite this version:}

Yohann Nicolas, Fouzia Allama, Marc Lepeltier, Julien Massin, Frédéric Castet, et al.. New Synthetic Routes towards Soluble and Dissymmetric Triphenodioxazine Dyes Designed for Dye-Sensitized Solar Cells. Chemistry - A European Journal, 2014, 20 (13), pp.3678-3688. 10.1002/chem.201303775 . hal-00968910

\section{HAL Id: hal-00968910 https://hal.science/hal-00968910}

Submitted on 26 Feb 2018

HAL is a multi-disciplinary open access archive for the deposit and dissemination of scientific research documents, whether they are published or not. The documents may come from teaching and research institutions in France or abroad, or from public or private research centers.
L'archive ouverte pluridisciplinaire HAL, est destinée au dépôt et à la diffusion de documents scientifiques de niveau recherche, publiés ou non, émanant des établissements d'enseignement et de recherche français ou étrangers, des laboratoires publics ou privés.

\section{(ㄷ)(1) $\$$}

Distributed under a Creative Commons Attribution - NonCommerciall 4.0 International 


\title{
New Synthetic Routes towards Soluble and Dissymmetric Triphenodioxazine Dyes Designed for Dye-Sensitized Solar Cells
}

\author{
Yohann Nicolas, ${ }^{*[\mathrm{a}]}$ Fouzia Allama, ${ }^{[\mathrm{a}]}$ Marc Lepeltier, ${ }^{[\mathrm{a}]}$ Julien Massin, ${ }^{[\mathrm{a}]}$ Frédéric Castet, ${ }^{[\mathrm{a}]}$ \\ Laurent Ducasse, ${ }^{[a]}$ Lionel Hirsch, $^{[b]}$ Zahia Boubegtiten, ${ }^{[c]}$ Gediminas Jonusauskas, ${ }^{[c]}$ \\ Céline Olivier, $^{[a]}$ and Thierry Toupance ${ }^{*[a]}$
}

\begin{abstract}
New $\pi$-conjugated structures are constantly the subject of research in dyes and pigments industry and electronic organic field. In this context, the triphenodioxazine (TPDO) core has often been used as efficient photostable pigments and once integrated in air stable n-type organic field-effect transistor (OFET). However, little attention has been paid to the TPDO core as soluble materials for optoelectronic devices, possibly due to the harsh synthetic conditions and the insolubility of many compounds. To benefit
\end{abstract}

from the photostability of TPDO in dye-sensitized solar cells (DSCs), an original synthetic pathway has been established to provide soluble and dissymmetric molecules applied to a suitable design for the sensitizers of DSC. The study has been pursued by the theoretical modeling of opto-electronic properties, the optical and electronic characterizations of dyes and elaboration of efficient devices. The discovery of new synthetic pathways opens the way to innovative designs of TPDO for materials used in organic electronics.

\section{Introduction}

Stimulated by the ever-ongoing efforts to fabricate cost-effective, lightweight, and efficient functional devices, organic alternatives to inorganic counterparts with tunable optoelectronic properties have attracted worldwide attention over the past two decades. ${ }^{[1]}$ Thus, the research of original $\pi$-conjugated structures is constantly evolving to address the main issues in organic electronics such as the fine tuning of energy band gaps $^{[2]}$ to improve light absorption, the understanding of intermolecular arrangement by molecular design ${ }^{[3]}$ to modulate the transfer integral and the charge carrier mobility in organic field-effect transistors (OFETs), or to improve the stability of the device. ${ }^{[4]}$

In this context, few new and efficient $\pi$-conjugated skeletons were directly inspired by the synthetic dyes and industrial

[a] Dr. Y. Nicolas, F. Allama, Dr. M. Lepeltier, Dr. J. Massin, Dr. F. Castet, Dr. L. Ducasse, Dr. C. Olivier, Prof. T. Toupance University of Bordeaux

Institut des Sciences Moléculaires, UMR 5255 CNRS 351 cours de la Libération, 33405 Talence (France) Fax: (+33) 540006994

Email:y.nicolas@ism.ubordeaux1.fr

[b] Dr. L. Hirsch

University of Bordeaux

Intégration des Matériaux aux Systèmes, UMR 5218 CNRS 16 avenue Pey Berland, 33607 Pessac Cedex (France)

[c] Dr. Z. Boubegtiten, Dr. G. Jonusauskas University of Bordeaux

Laboratoire Ondes et Matière d'Aquitaine, UMR 5796 CNRS 351 cours de la Libération, 33405 Talence (France) organic pigments. ${ }^{[5]}$ For instance, the diketopyrrolopyrrole core included in Ferrari-red pigment and isoindigo core has been recently and widely used as monomer for p-type polymers in organic photovoltaics. ${ }^{[6]}$ Perylenes, which are also well-known pigments, were employed to increase the air-stability of n-type materials for OFETs. ${ }^{[7]}$ The same cores have been successfully integrated in the design of sensitizers for dye-sensitized solar cells (DSCs). ${ }^{[8]}$ On the other hand, motivated by the limited metal (as ruthenium or zinc) resource and their good flexibility in molecular tailoring, metal-free organic dyes have been developed with success for DSCs. ${ }^{[9]}$ The main efforts have been devoted to the enhancement of the light-harvesting properties of the organic dyes, the optimization of the first oxidation potential level, the control of the internal charge-transfer processes and the improvement of the dye photostability. ${ }^{[10]}$ So far, the donor- $\pi$-bridge-acceptor (D- $\pi-A)$ design, which includes electron donor and acceptor groups connected through a $\pi$ conjugated linker, appeared to be one of the most promising arrangement to get efficient organic dyes for DSCs.

On the other hand, triphenodioxazines (TPDOs), which are well-known industrial molecules, ${ }^{[11]}$ have been used as photostable pigments (i.e., C.I. PV23) and air-stable semiconducting materials in OFET. ${ }^{[12]}$ Recently, TPDO derivatives have also shown high dichroic luminescence in host liquid crystals, ${ }^{[13]}$ which opens the window for their integration into advanced optical devices. In addition, for the first time, a TPDO derivative has been integrated as electro-active material in organic solar cells to enhance the photoconversion efficiency for MEHPPV:PCBM bulk heterojunctions. ${ }^{[14]}$ Related compounds as phenoxazine derivatives have already been grafted on titanium oxide for efficient DSSCs due to the facile modification of their structures, low dye aggregations, and electron-donating prop- 
erties. ${ }^{[15]}$ Another $\pi$-conjugated pentacycle containing two $\mathrm{sp}^{2}$ nitrogen atoms and two oxygen atoms as TPDO has newly been synthesized to increase the stability of acene derivatives and to modulate the aromaticity. ${ }^{[16]}$

TPDO derivatives can therefore be envisioned as a $\pi$-conjugated platform to be integrated into $D-\pi-A$ dye architectures. Nevertheless, the low solubility in common solvents and harsh synthetic conditions has limited their integration into organic electronic devices. Moreover, only one example of dissymmetric TPDO have been reported so far. ${ }^{[17]}$ To implement stable TPDO structures for DSCs, we herein describe new synthetic routes extending the possible design towards soluble and unsymmetrical TPDOs substituted by numerous chemical functions such as tert-butyl solubilizing groups, electron-withdrawing or electron-releasing groups on well-defined positions (Scheme 1). Optical and electronic properties along with photobleaching of these new dyes were determined and further rationalized by the means of theoretical modeling. Finally, TPDO dyes yielded very promising power conversion efficiencies (PCE up to $6.3 \%$ ) in DSCs.
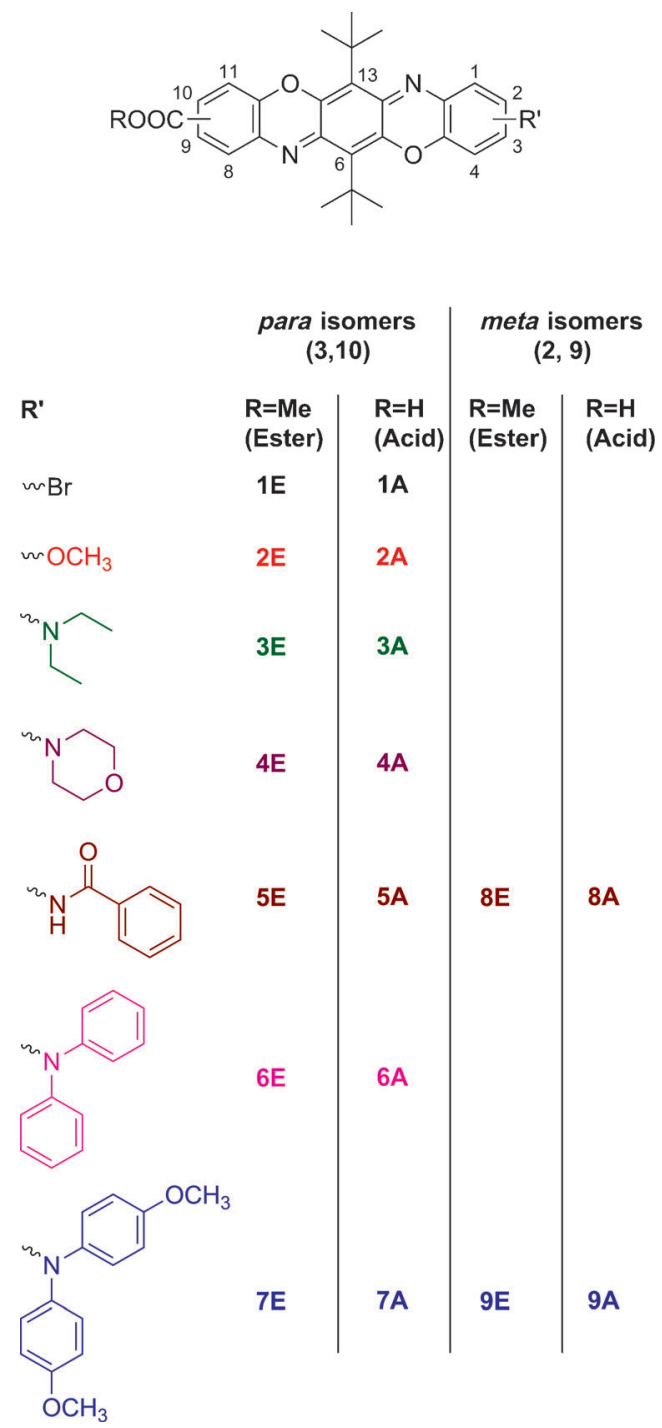

Scheme 1. TPDO dyes designed for DSC.

\section{Results and Discussion}

\section{Synthesis of dyes}

The conventional synthetic pathway towards TPDOs ${ }^{[11 c, 18]}$ (Scheme 2) based on the nucleophilic substitution of tetrahalogeno-1,4-benzoquinone by aniline derivatives followed by an<smiles>[X]C1=C(Nc2ccccc2)C(=O)C([X])=C(Nc2ccccc2)C1=O</smiles><smiles>[X]c1c2c(c([X])c3c1=Nc1ccccc1O3)=Nc1ccccc1OC2=[X]</smiles>

Scheme 2. Usual synthetic pathway toward TPDOs. Reaction conditions: i) AcOEt; ii) $\mathrm{PhNO}_{2}$, benzoyl chloride, heat.

oxidation/cyclization process under harsh conditions has been unsuccessfully tested to synthesize the soluble di-alkylated TPDO 10 from 2,5-di-tert-butyl-3,6-dichlorobenzo-1,4-quinone 12.

Consequently, a new synthetic strategy involving two main steps (Scheme 3 ) has been established and initially applied to the simplest design of the soluble TPDO 10, by including tert-<smiles>Cc1cccc(OC2=C(C(C)(C)C)C(=O)C(Oc3ccccc3[N+](=O)[O-])=C(C(C)(C)C)C2=O)c1[N+](=O)[O-]</smiles><smiles>CC(C)(C)c1c(O)c(Oc2ccccc2N)c(C(C)(C)C)c(O)c1Oc1ccccc1N</smiles>

Scheme 3. New synthetic pathway toward soluble TPDO 10. i) DMF, $100^{\circ} \mathrm{C}$, $10 \mathrm{~h}$; ii) $\mathrm{Fe}, \mathrm{THF}, \mathrm{AcOH}$, reflux, $1.5 \mathrm{~h}$; iii) Chloranil or air, overnight.

butyl groups as a solubilizing moiety. Firstly, the nucleophilic substitution of halogenobenzoquinone 12 by potassium 2-nitrophenoxide 11 resulted in the bond formation between the oxygen and the internal cycle.

Then, compound 13 was reduced either by sodium dithionite in water/ethanol or iron/acetic acid mixture to give the amine functions while leading to the hydroquinone. Subsequent oxidation of the hydroquinone moiety by air or chloranil was followed by immediate intramolecular condensation between the amino groups and the carbonyl functions of the 
quinone to yield the new TPDO 10. As requested for further integration in DSC, compound $\mathbf{1 0}$ was soluble in common organic solvents as tetrahydrofuran, chloroform and pentane.

To reach the target dissymmetric push-pull molecules built from the soluble TPDO core, three different synthetic routes can be considered. First of all, two different ortho-nitrophenol derivatives could be sequentially added to the quinone 12 followed by the cyclisation step described for 10. Unfortunately, this method led to low yield when the nitrophenol is substituted by a deactivated group in the para position such as methyl 4-hydroxy-3-nitrobenzoate. The second choice might consist in synthesizing a dibrominated TPDO and, then, introducing various functional groups through catalytic couplings. For example, the diphenylamine substituent has been introduced by a Buchwald-Hartwig reaction with 1:1 molar stoichiometric ratio but led in equal quantity to the mono- and bis-adduct. As the unsymmetrical TPDOs were not straightforwardly obtained by this second pathway, a third methodology has been developed. Thus, the most efficient synthetic way appeared to be the formation of the first oxazine cycle by the reaction between methyl 4-amino-3-hydroxybenzoate 14 and quinone 12 (Scheme 4). As the phenoxazine 15 was less reactive than the quinone 12, the reaction stopped after the first addition of aminophenol 14. Then, nucleophilic substitution of the remaining chlorine atom in the tricyclic intermediate 15 by 5 -bromo2-nitrophenol followed by a reduction/oxidation step as described for $\mathbf{1 0}$ led to the pre-functionalized dissymmetric TPDO $1 \mathrm{E}$. During the two first steps, the amount of byproducts was limited and the unreacted substrates could be easily recycled. Then, the substitution of the bromine atom in $1 \mathrm{E}$ allowed us to introduce many donor groups as diethylamine, benzamide, diphenylamine, and di(4-methoxyphenyl)amine, ${ }^{[19]}$ and led to various TPDO ester derivatives (3E, 5E, 6E, 7E, respectively). It is also worth mentioning that, during the Buchwald-Hartwig coupling with arylamine substrates, transesterification occurred with sodium tert-butoxide. Consequently, the released sodium methoxide reacted on the brominated position to provide the methoxytriphenodioxazine ester derivative $2 \mathrm{E}$. On the other hand, the use of the 4-substituted aminophenol and nitrophenol instead of the 5-subtituted isomers led to new TPDO isomers. Thus, meta derivatives analogous to TPDO para-substituted by benzamide and diphenyl amine groups have been synthesized (8E, 9E). Alternatively, the following electron-releasing group (morpholine) was directly introduced by the use of the substituted nitrophenol instead of the brominated derivative to lead to the TPDO 4E. Finally, saponification of the TPDO ester derivatives followed by the acidification of reaction mixture yielded the corresponding carboxylic acids (1 A-9 A).

Therefore, the new synthetic strategies open the way for original soluble and dissymmetric TPDOs substituted by new chemical functions with a fine control of the position isomerism and led to nine suitable dyes for DSCs (Scheme 1).

\section{Crystallography}

Although solution NMR spectroscopy and HRMS data were consistent with the expected structures for the triphenodioxazines described above, and after growing suitable crystals by slow evaporation of solutions in acetonitrile, the crystal structure of the intermediates 15, 16 (see the Supporting Information), and the ester derivative $6 \mathrm{E}$ (Figure 1) were solved by $\mathrm{X}$ ray diffraction analysis to prove the isomerism and the structure of central rings. Each structure was consistent with that expected from the synthetic pathway. Moreover, the positions of the three internal rings and the tert-butyl substituents have been established and revealed the distortion of the fused rings due to steric hindrance caused by the bulky alkyl groups (bending angle $\approx 3^{\circ}$, twist angle $\approx 20^{\circ}$ ). Overall, the TPDO core was almost planar and should be highly conjugated, as further confirmed by quantum chemical calculations. Finally, the structures corroborated the invariability of isomerism throughout the synthesis.<smiles>CC(=O)c1ccc(N)c(O)c1</smiles><smiles>COC(=O)c1ccc2nc3c(C(C)(C)C)c(Oc4cc(Br)ccc4[N+](=O)[O-])c(=O)c(C(C)(C)C)c-3oc2c1</smiles><smiles></smiles>

Scheme 4. Synthesis of unsymmetrical TPDO dye $6 \mathrm{~A}$. i) $\mathrm{NaHCO}_{3}$, dimethylacetamide (DMAc), $80^{\circ} \mathrm{C}$, overnight; ii) 5 bromo 2 nitrophenol, $t \mathrm{BuOK}, \mathrm{DMAc}, 80^{\circ} \mathrm{C}$, $48 \mathrm{~h}$; iii) 1) $\mathrm{Na}_{2} \mathrm{~S}_{2} \mathrm{O}_{4}$, ethanol/water, heat at reflux, overnight; 2$)$ chloranil, $\mathrm{CHCl}_{3}$, overnight; iv) Diphenylamine, $\left[\mathrm{Pd}_{2}\left(\mathrm{dba}_{3}\right]\right.$, diphenylphosphine ferrocene, $t \mathrm{BuOK}$, toluene, heat at reflux, $3 \mathrm{~h}$; v) $\mathrm{KOH}, n \mathrm{Bu}_{4} \mathrm{NF}$, THF, toluene, heat at reflux, $4 \mathrm{~h}$. 

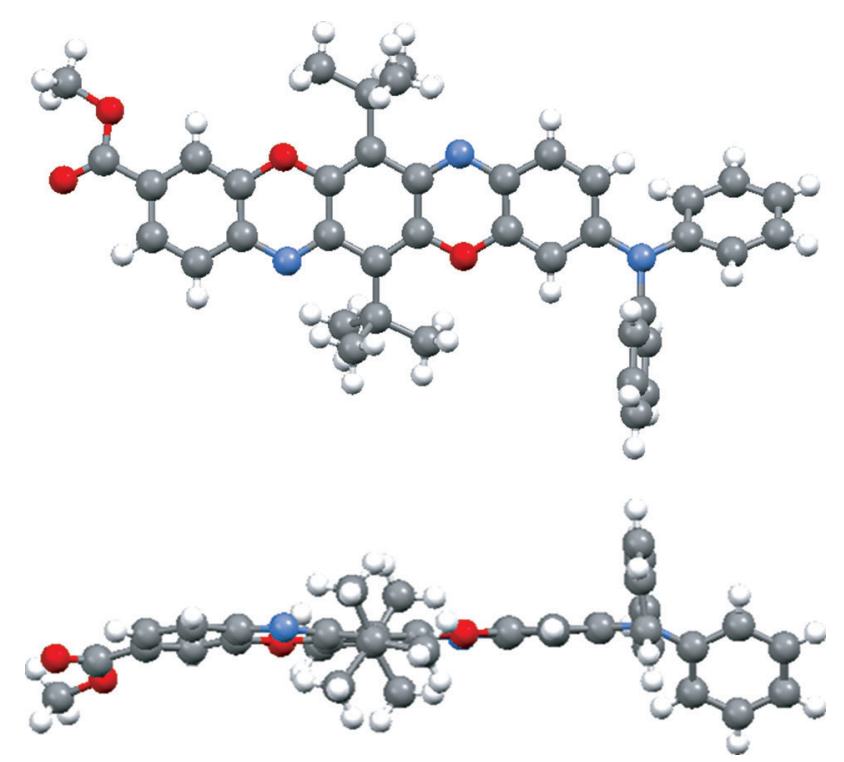

Figure 1. $\mathrm{X}$ ray crystal structure of $6 \mathrm{E}$.

\section{Electronic properties}

The combination of UV/Visible absorption and time-resolved emission spectroscopic investigations along with electrochemistry studies allowed an investigation into whether these new dyes showed the expected electronic properties to be efficient in DSCs (Table 1). As the acidic derivatives were only sparingly soluble in polar solvents, the study was focused on the ester analogues. Moreover, the absorption spectra of ester and acid derivatives were similar (see the Supporting Information). First of all, the absorption properties of each TPDO ester dyes were examined to better understand the effect of the nature and position of the electron-donating group in the TPDO core.

\begin{tabular}{|c|c|c|c|c|c|}
\hline Dye & $\begin{array}{l}\lambda_{\max }[\mathrm{nm}] \\
(\log \varepsilon)^{[\mathrm{a}]}\end{array}$ & $\begin{array}{l}\lambda_{\text {Fluo }}[\mathrm{nm}] \\
\left(\Phi_{\text {Fluo }}[\%]\right) \\
\{\tau \text { [ps] }\}^{[b]}\end{array}$ & $\begin{array}{l}E_{(\mathrm{S}+/ \mathrm{s})} \\
([\mathrm{V}] \mathrm{vs} . \\
\mathrm{NHE})^{[\mathrm{cc}]}\end{array}$ & $\begin{array}{l}E_{\left(\mathrm{S}+/ \mathrm{S}^{*}\right)} \\
([\mathrm{V}] \mathrm{vs} . \\
\mathrm{NHE})^{[\mathrm{d}]}\end{array}$ & $\begin{array}{l}\text { Photodestr. } \\
\text { yield } \\
\left(10^{6}\right)^{[\mathrm{e}]}\end{array}$ \\
\hline $1 \mathrm{E}$ & $521(4.7)$ & $547(9.4)\{440\}$ & 1.50 & 0.91 & 5.3 \\
\hline $2 \mathrm{E}$ & $528(4.5)$ & $633(3.1)\{810\}$ & 1.20 & 1.06 & 13 \\
\hline $3 E$ & $581(4.5)$ & $\mathrm{N} / \mathrm{A}$ & 0.80 & 1.16 & \\
\hline $4 \mathrm{E}$ & $551(4.4)$ & $702(6.6)\{330\}$ & 0.91 & 1.17 & 21 \\
\hline $5 \mathrm{E}$ & $536(4.7)$ & $624(23.6)\{980\}$ & 1.20 & 1.07 & 9.1 \\
\hline $6 \mathrm{E}$ & $571(4.7)$ & $\begin{array}{l}687(2.5)\{123 \\
623\}\end{array}$ & 0.97 & 1.01 & 5.0 \\
\hline $7 E$ & $585(4.6)$ & $752(0.87)\{65\}$ & 0.87 & 1.10 & 4.5 \\
\hline $8 \mathrm{E}$ & $512(4.6)$ & $568(18.5)\{870\}$ & 1.34 & 1.20 & 4.2 \\
\hline $9 E$ & $450(4.4)$ & $\begin{array}{l}546(0.16)\{900 \\
3100\}\end{array}$ & 0.87 & $\mathrm{~N} / \mathrm{A}$ & 27 \\
\hline
\end{tabular}

[a] Absorption maximum wavelength in visible range of the dye solution in $\mathrm{CH}_{2} \mathrm{Cl}_{2}$ and molar absorption coefficient. [b] Emission maximum wave length in $\mathrm{CH}_{2} \mathrm{Cl}_{2}$, quantum yield of fluorescence, and fluorescence life time. [c] Cyclic voltammetry measured in a solution of $0.1 \mathrm{M} \mathrm{Bu}_{4} \mathrm{NPF}_{6}$ in $\mathrm{CH}_{2} \mathrm{Cl}_{2}$, versus $\mathrm{Fc}^{+} / \mathrm{Fc}$, corrected by adding $0.7 \mathrm{~V}^{[33]}$ [d] Estimated by sub tracting the onset of the absorption band in solution to $E_{(\mathrm{S}+/ \mathrm{S})}$. [e] Mea sured in $\mathrm{CH}_{2} \mathrm{Cl}_{2}$ solution.
Each TPDO ester dye exhibited a strong and broad absorption band in the visible range with maximum molar absorptivity $(\varepsilon)$ higher than $40000 \mathrm{~L} \mathrm{~mol}^{-1} \mathrm{~cm}^{-1}$ in dichloromethane. Furthermore, the strongest electron-releasing groups (ERG) as diarylamine and dialkylamine induced a significant redshift of the maximum absorption wavelength for the dyes substituted in the para position (Figure 2). Thus, compared to that of the bro-
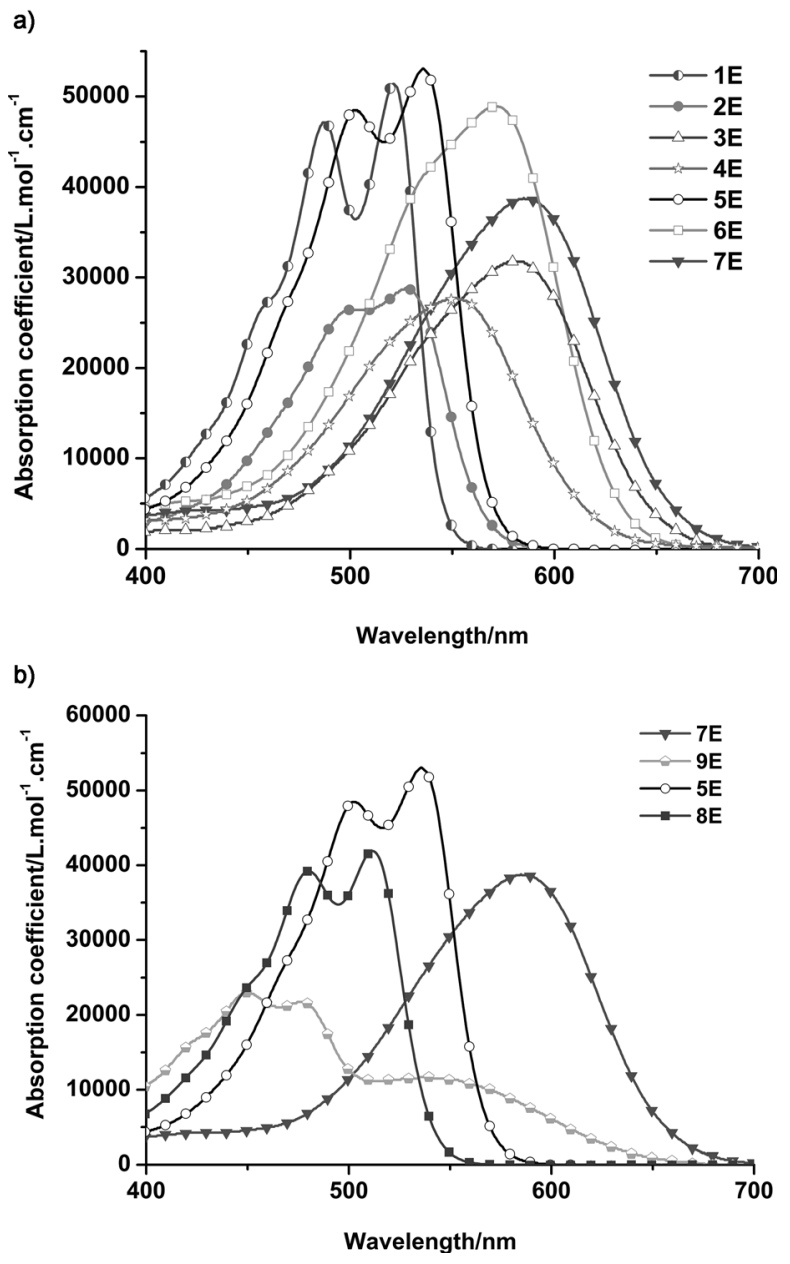

Figure 2. Absorption spectrum of a) para isomers, b) meta isomers and their corresponding para isomers in dichloromethane.

minated derivative $1 \mathrm{E}$, the maximum absorption band of $7 \mathrm{E}$ was redshifted by more than $60 \mathrm{~nm}$ whereas the meta-substituted analogue $9 \mathrm{E}$ led to a blueshift of $71 \mathrm{~nm}$. These behaviors were consistent with the expected push-pull effect and the results of theoretical modeling.

Moreover, the vibrational fine structure of absorption bands linked to the rigidity of the TPDO core disappeared in the case of the push-pull structures due to the extension of frontier orbitals through free rotational bond. In the case of TPDOs metasubstituted by a strong ERG (i.e., compound 9E), a second band in the red range appeared extending the absorption from 350 to $620 \mathrm{~nm}$ (Figure 2). In contrast to the benzamide substituent, the absorption band redshifted from the meta to 
the para isomer. Finally, the absorption band of dyes was centered on the strongest emissive part of the solar spectrum.

Fluorescent quantum yields and lifetimes were also determined. As expected, the fluorescent efficiency of push-pull dyes or molecules substituted by heaviest atoms were weak compared to the other dyes. We should note that a strong discrepancy in the correlation between fluorescence quantum yield and fluorescence lifetime appears for the meta-substituted compound $9 \mathrm{E}$ indicating an implication of multiple relaxation pathways from the excited state. Furthermore, some of these dyes appeared to be highly photostable with a photodestruction yield of $5.3 \times 10^{-6}, 5.0 \times 10^{-6}$, and $4.5 \times 10^{-6}$ for $1 \mathrm{E}, 6 \mathrm{E}$, and $7 \mathrm{E}$ respectively, which is better than fluorescein isocyanate $\left(75 \times 10^{-6}\right)$ used as a reference for photodestruction measurements. ${ }^{[20]}$ By contrast, meta-substituted or alkyl-substituted derivatives were much more unstable with, for instance, a photodestruction yield of $27 \times 10^{-6}$ for $9 \mathrm{E}$.

The ground-state oxidation potential $\left(E_{(\mathrm{S}+/ \mathrm{S})}\right)$ and the highest occupied molecular orbital/lowest unoccupied molecular orbital (HOMO-LUMO) transition energy values were evaluated by cyclic voltammetry and absorption/emission spectroscopy (Table 1). Each compound could be reversibly oxidized, consistent with the formation of stable radical-cations, which is a key requirement for efficient electronic processes in DSCs. The $\left(E_{(S+/ S)}\right)$ values fall within a wide range, that is, $0.8-1.5 \mathrm{~V}$ versus the normal hydrogen electrode (NHE), but are each more positive than that of the iodide/triiodide redox shuttle revealing that the ground-state regeneration is energetically favorable for DSC applications. On the other hand, the LUMO levels, deduced from the values of half-wave oxidation potential and the onset of the optical gaps were between 0.9 and $1.2 \mathrm{~V}$ versus $\mathrm{NHE}$, which yields the free energy necessary to transfer an electron from the first excited state of the chromophore to the $\mathrm{TiO}_{2}$ conduction band. On the basis of the $\left(E_{(\mathrm{s}+/ \mathrm{s})}\right)$ and LUMO energy values, a functional DSC elaborated from the TPDO-based sensitizers, $\mathrm{TiO}_{2}$ semi-conductor, and the iodide/ triiodide redox shuttle should be energetically favorable. ${ }^{[21]}$

\section{Quantum chemical calculations}

All calculated structures show a slight distortion of the TPDO moiety $\left(\approx 5^{\circ}\right)$, due to the steric hindrance induced by the tertbutyl groups, in close agreement with the X-ray diffraction data. Moreover, all compounds exhibit a bending in their aromatic core of about $20^{\circ}$ (Figure 3), which is consistent with an almost planar structure as observed in their crystalline state.

The low-energy transition energies and wavelengths computed at the MPW1K/6-311G(d) level are reported in Table 2, along with the corresponding oscillator strengths and the nature of the main electronic excitations involved in the lowlying optical transitions. The shape of the relevant molecular orbitals (MOs), as well as the simulated absorption spectra, can be found in Supporting Information. As illustrated in Figure S6 (the Supporting Information), the transition wavelengths $\lambda_{\text {ge }}$ computed using the MPW1K functional correlate nicely with the experimental ones: despite TD-DFT calculations globally overestimate the $S_{0} \rightarrow S_{1}$ transition wavelengths, the relative

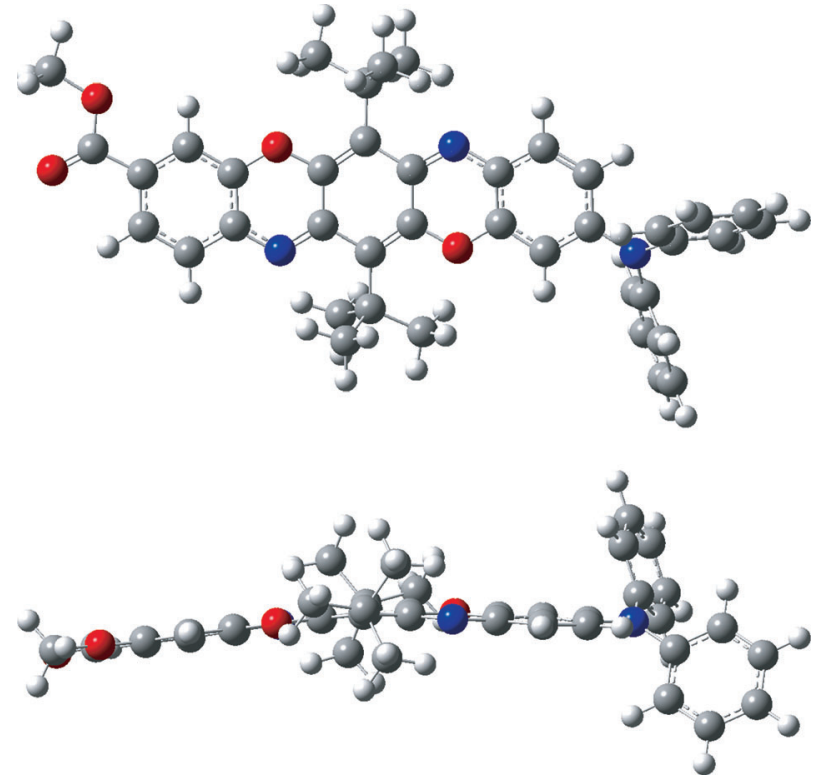

Figure 3. Front and side views of $6 \mathrm{E}$, as optimized at the B3LYP/6 $31+G(d, p)$ level.

Table 2. Transition energies $\left(\Delta E_{\mathrm{ge},} \mathrm{eV}\right)$, wavelengths $\left(\lambda_{\mathrm{ge}}, \mathrm{nm}\right)$, oscillator strengths $\left(f_{\text {ge }}\right)$, main electronic transitions and associated $\mathrm{Cl}$ weights, charge transferred $\left(q^{\mathrm{CT}},|\mathrm{e}|\right), \mathrm{CT}$ distance $\left(d^{\mathrm{CT}}, \AA\right)$, and dipole moment var iation $(\Delta \mu, \mathrm{D})$, calculated at the TD MPW1K/6 311G(d) level for the lowest energy excitation states of the dyes.

\begin{tabular}{|c|c|c|c|c|c|c|c|}
\hline Mol. & $\Delta E_{\mathrm{ge}}$ & $\lambda$ & $f_{\mathrm{ge}}$ & Dominant transitions & $q^{C \top}$ & $d^{C T}$ & $\Delta \mu$ \\
\hline $2 \mathrm{E}$ & 2.289 & 542 & 1.636 & $\mathrm{H} \rightarrow \mathrm{L}(0.70236)$ & 0.434 & 1.387 & 2.886 \\
\hline $3 E$ & 2.072 & 598 & 1.760 & $\mathrm{H} \rightarrow \mathrm{L}(0.70189)$ & 0.489 & 2.246 & 5.291 \\
\hline $4 \mathrm{E}$ & 2.149 & 577 & 1.747 & $\mathrm{H} \rightarrow \mathrm{L}(0.70174)$ & 0.480 & 2.148 & 4.941 \\
\hline $5 \mathrm{E}$ & 2.264 & 548 & 1.788 & $\mathrm{H} \rightarrow \mathrm{L}(0.70175)$ & 0.434 & 1.287 & 2.664 \\
\hline $6 \mathrm{E}$ & 2.109 & 588 & 1.816 & $\mathrm{H} \rightarrow \mathrm{L}(0.69746)$ & 0.533 & 2.814 & 7.221 \\
\hline $7 E$ & 2.057 & 603 & 1.842 & $H \rightarrow L(0.69537)$ & 0.553 & 3.114 & 8.242 \\
\hline $8 \mathrm{E}$ & 2.421 & 512 & 1.526 & $\mathrm{H} \rightarrow \mathrm{L}(0.70176)$ & 0.443 & 0.866 & 1.869 \\
\hline \multirow[t]{5}{*}{$9 \mathrm{E}$} & 2.245 & 552 & 1.070 & $\mathrm{H} \rightarrow \mathrm{L}(0.67518)$ & 0.680 & 3.716 & 12.137 \\
\hline & & & & $\mathrm{H} \quad 1 \rightarrow \mathrm{L}(0.17906)$ & & & \\
\hline & 2.780 & 446 & 0.587 & $\mathrm{H} 2 \rightarrow \mathrm{L}(0.17871)$ & & & \\
\hline & & & & $\mathrm{H} \quad 1 \rightarrow \mathrm{L}(0.65880)$ & & & \\
\hline & & & & $\mathrm{H} \rightarrow \mathrm{L}(0.15533)$ & & & \\
\hline
\end{tabular}

values are well reproduced. It is also worth mentioning that deviations with respect to experiments become larger as the wavelengths increase. This last shortcoming is corrected when using the long-range corrected $\omega$-B97X-D functional. However, the agreement with experiment regarding the relative $\lambda_{\text {ge }}$ values is deteriorated compared to MPW1K (see Table S3 and Figure S7, the Supporting Information), so that only the MPWIK results will be discussed further. The lowest-energy absorption band of para-substituted compounds is dominated by a HOMO to LUMO electron excitation. The lowest $S_{0} \rightarrow S_{1}$ transition energies are obtained for molecules $3 \mathrm{E}, 6 \mathrm{E}$, and $7 \mathrm{E}$, which imply the strongest electron-releasing groups. In these three dyes, the HOMO is spread throughout the molecule whereas the LUMO is confined onto the TPDO core, indicative of a charge transfer from the donor unit to the aromatic 
moiety. In accordance with the push-pull effects revealed by the spatial distribution of the MOs, and with the redox potential measured by electrochemistry, these compounds have the smallest HOMO-LUMO gaps among the series. Consistent with the UV/Vis measurements, meta-substituted compounds $8 \mathrm{E}$ and $9 \mathrm{E}$ display smaller maximum absorption wavelengths than their para-substituted analogues $5 \mathrm{E}$ and $7 \mathrm{E}$. The significant blueshift observed when going from para to meta substitution is a consequence of a decrease in the efficiency of the electron $\pi$-conjugation in the ground state, as illustrated Figure S27 (the Supporting Information). The larger electron $\pi$-conjugation of para-substituted compounds is further confirmed by their higher stability ( $5 \mathrm{E}$ and $7 \mathrm{E}$ are more stable than $8 \mathrm{E}$ and $9 \mathrm{E}$ by 2.7 and $0.8 \mathrm{kcal} \mathrm{mol}^{-1}$, respectively), as well as by the detailed analysis of the bond distances along the TPDO moiety (Table S5, the Supporting Information), which reveals a more pronounced contribution of the zwitterionic form $\left(D^{+}-\pi-A^{-}\right)$in the ground-state wave function. To gain more quantitative insights on the charge-transfer phenomena occurring upon photoexcitation of the dyes, the amount of charge transferred $\left(q^{\mathrm{CT}}\right)$, as well as the CT distance $\left(d^{\mathrm{CT}}\right.$, that is, the spatial extent of the charge delocalization) were evaluated from the difference $\Delta \rho$ between the ground- and excited-state electron densities, using the procedure described in Ref. [22]. In this procedure, $\Delta \rho$ is split into two contributions, $\rho^{+}$and $\rho^{-}$, which correspond respectively to the increase $(\Delta \rho>0)$ and decrease $(\Delta \rho<0)$ of the density. The amount of charge transferred, $q^{\mathrm{CT}}$, is defined as the integral over space of the $\rho^{+}$(or $\rho^{-}$) function, whereas $d^{C T}$ is the distance separating the barycenters of these two functions. The $q^{c T}$ and $d^{c T}$ values computed at the MPW1K/6-311G(d) level, as well as the light-induced dipole moment variation, are gathered in Table 2 . Variation density plots are reported in the Supporting Information for all dyes. Figure 4 illustrates the light-induced density changes calculated for $7 \mathrm{E}$ and its meta-analogue, $9 \mathrm{E}$.

As a general trend, it is found that the transition wavelengths within the series globally increase with $\Delta \mu$ and the CT distance. As illustrated in Figures S25 and S26 (the Supporting Information), the four dyes exhibiting the larger $C T$ distances ( $3 \mathrm{E}, 4 \mathrm{E}, 6 \mathrm{E}$, and $7 \mathrm{E}$, in which $d^{\mathrm{CT}}>2 \AA$ ) give rise to larger wavelengths, whereas compounds $2 \mathrm{E}, 5 \mathrm{E}$, and $8 \mathrm{E}$, in which the charge transfer occurs over smaller distances, display smaller transition wavelengths. A noticeable exception to this trend is observed for the meta-substituted compound $9 \mathrm{E}$, for which the wavelength is unexpectedly low owing to its dipole moment variation and CT distance. The large values of $\Delta \mu$ and $d^{C T}$ calculated for this compound arise from a small spatial overlap between the electron-donating and electron-accepting regions, as confirmed by the small value of the Tozer's parameter $^{[23]}$ (see Table S2, the Supporting Information). As discussed above, the small maximum absorption wavelength obtained for $9 \mathrm{E}$ is a consequence of a poor electron conjugation in the ground state. One also notes that, contrary to the corresponding para compounds, the light-induced density change is not localized on carboxyl group in meta derivatives, which is expected to reduce the efficiency of the photoexcited electron injection into the $\mathrm{TiO}_{2}$ conduction band.

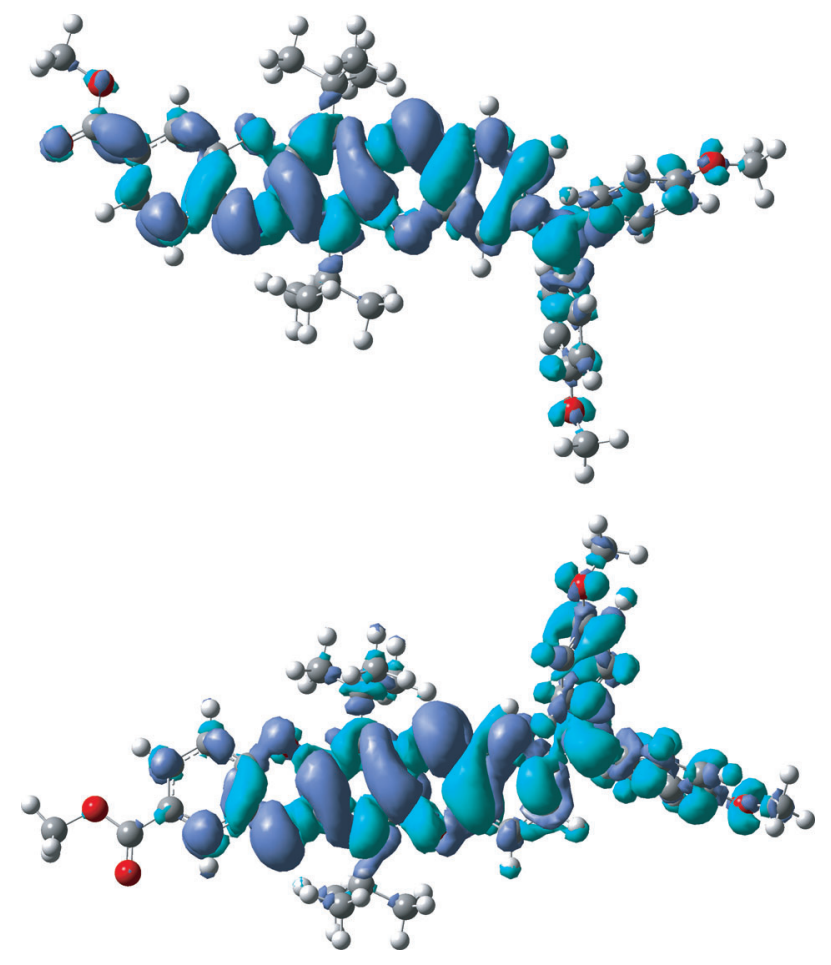

Figure 4. Difference between excited and ground state densities $(\Delta \rho)$ for 7E (top) and 9E (bottom), calculated at the MPW1K/6 311G(d) level. Blue and violet lobes are associated to positive and negative differences, respec tively.

\section{TPDO-Sensitization of porous $\mathrm{TiO}_{2}$ films and performances of DSC}

Dyes 2 A-9 A were first chemisorbed onto $3 \mu \mathrm{m}$-thick nanoparticulate anatase $\mathrm{TiO}_{2}$ films in the presence or absence of cheno-deoxycholic acid (CDCA) as a co-adsorbent. ${ }^{[24]}$ Regardless of the dye nature, the shape of absorption spectrum of the dye-modified $\mathrm{TiO}_{2}$ layers showed strong and broad absorption bands in the visible range (Figure 5). Moreover, a significant hypsochromic shift of the maximum absorption band compared to the spectrum in solution was clearly evidenced (Figure 5), this effect being even more pronounced without co-adsorbent. This blueshift could be attributed to the dye aggregation at the oxide surface but also to the coupling between the dyes and $\mathrm{TiO}_{2}$ as it was recently proposed in the case of triarylamine dyes. ${ }^{[25]}$

Then, two types of devices were elaborated involving TPDOsensitized nanoporous $\mathrm{TiO}_{2}$ films of two different thicknesses coated over transparent conductive electrode as anode, a commercial iodide/triiodide based liquid electrolyte and a platinum counter electrode (see the Experimental Section). For thick porous $\mathrm{TiO}_{2}$ films $\left(9 \mu \mathrm{m}\right.$-thick $\mathrm{TiO}_{2} 20 \mathrm{~nm}$ nanoparticles $+6 \mu \mathrm{m}$ light-scattering $\mathrm{TiO}_{2}$ particles), the para-substituted dyes $2 \mathrm{~A}-$ $7 \mathrm{~A}$ showed good photovoltaic responses with power conversion efficiency $(P C E, \eta)$ ranging from 1.91 to $6.30 \%$ under AM1.5G illumination $\left(100 \mathrm{~mA} \mathrm{~cm}^{-2}\right)$, the best performances being reached with the arylamine donor groups (Table 3 and the Supporting Information). Thus, the diphenylamine-substi- 

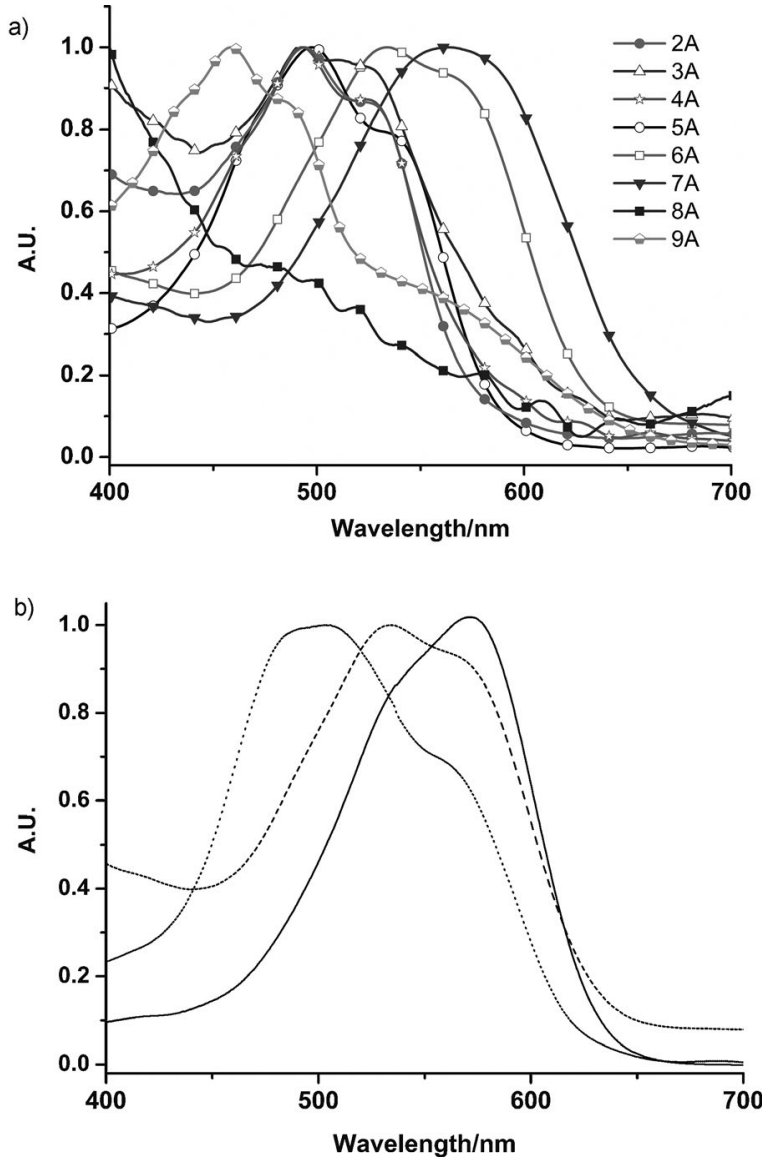

Figure 5. a) Normalized spectrum of thin nanoporous $\mathrm{TiO}_{2}$ film sensitized by dyes $2 \mathrm{~A} 9 \mathrm{~A}$; b) Absorption spectrum of a $6 \mathrm{E}$ solution ( ), a thin film sen sitized by $6 \mathrm{~A}$ only ( $\quad$ ) and with co adsorbent CDCA (.....).

\begin{tabular}{|c|c|c|c|c|}
\hline Dyes & $\begin{array}{l}J_{s c} \\
{\left[\mathrm{mAcm}^{2}\right]^{[\mathrm{a}]}}\end{array}$ & $\begin{array}{l}V_{o c} \\
{[\mathrm{mV}]^{[\mathrm{b}]}}\end{array}$ & $\begin{array}{l}\text { ff } \\
{[\%]^{[c]}}\end{array}$ & $\begin{array}{l}\eta \\
{[\%]^{[d]}}\end{array}$ \\
\hline $2 \mathrm{~A}$ & 6.36 & 649 & 67.6 & 2.79 \\
\hline $3 \mathrm{~A}$ & 4.57 & 578 & 72.1 & 1.91 \\
\hline $4 \mathrm{~A}$ & 6.77 & 640 & 68.2 & 2.96 \\
\hline $5 \mathrm{~A}$ & 8.70 & 679 & 72.8 & 4.30 \\
\hline $6 \mathrm{~A}$ & 12.44 & 685 & 74.1 & 6.30 \\
\hline $7 \mathrm{~A}$ & 9.93 & 644 & 72.4 & 4.62 \\
\hline $8 \mathrm{~A}$ & 1.18 & 553 & 70.7 & 0.46 \\
\hline $9 \mathrm{~A}$ & 3.79 & 634 & 71.5 & 1.72 \\
\hline
\end{tabular}

[a] Short circuit current density. [b] Open circuit photovoltage. [c] Fill factor. [d] Power conversion efficiency.

tuted TPDO $6 \mathrm{~A}$ led to $\eta$ of $6.30 \%$ with a short-circuit current density $\left(J_{\mathrm{sc}}\right)$ of $12.44 \mathrm{mAcm}^{-2}$, an open-circuit photovoltage $\left(V_{\text {oc }}\right)$ of $685 \mathrm{mV}$ and a fill factor (ff) of $74.1 \%$. This performance constitutes one the best ever reported for such a simple design. ${ }^{[22]}$ Furthermore, the incident photon-to-electron conversion efficiency (IPCE) measured under light bias for the best cells (see the Supporting Information) exhibited a maximum

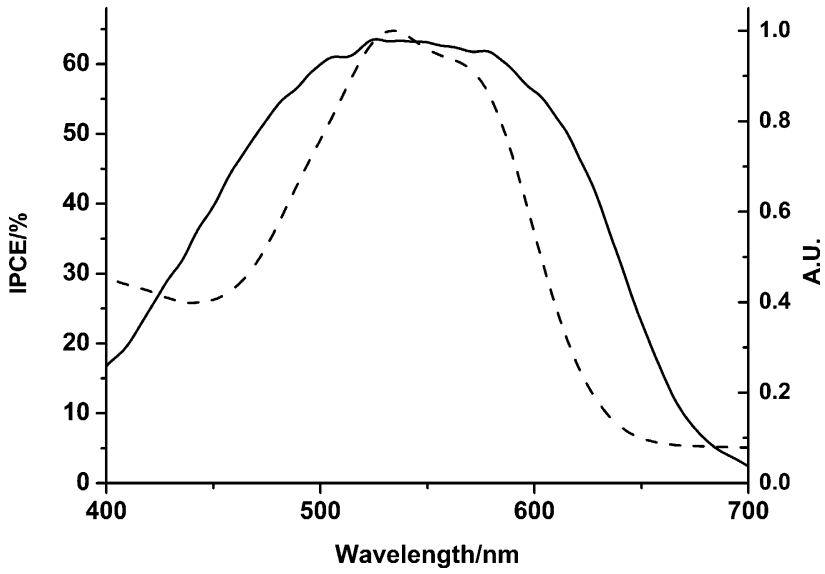

Figure 6. IPCE of 6 A sensitized DSC ( ) compared to the absorption spec trum $6 \mathrm{~A}$ sensitized $\mathrm{TiO}_{2}$ layer. ( ).

efficiency centered on the maximum absorption band of thin film to exceed $60 \%$ in the case of $6 \mathrm{~A}$ (Figure 6 ). The good agreement between the photocurrent action spectrum and the UV/Visible absorption spectrum of the $6 \mathrm{~A}$-modified $\mathrm{TiO}_{2}$ electrodes definitely shows that the sensitization process actually takes place. For the $\mathbf{9} \mathrm{A}$ dye, the photoconversion was equally observed at 450 and $550 \mathrm{~nm}$, independently to the nature of absorption bands. By contrast, the meta isomers $\mathbf{8} \mathbf{A}-$ $9 \mathrm{~A}$ led to a drastic collapse of the power conversion efficiencies mainly related to a collapse in $J_{\mathrm{sc}}$. For instance, the photocurrent density for the $\mathbf{9 A}$ dropped by $62 \%$ from para to meta substitution, which evidences the key role of the para substitution to reach good photoconversion efficiencies. As discussed above, the lack of frontier orbital electron density and light-induced density changes on the anchoring group could explain lower injection rates leading to the downfall of $J_{\text {sc }}$.

Recent development in DSCs have shown that the replacement of the corrosive and volatile iodide/triiodide based liquid electrolyte by other redox shuttles (as $\left.\mathrm{Co}^{2+} / \mathrm{Co}^{3+}\right)^{[26]}$ or solid hole-transporters ${ }^{[10]}$ requires the use of thinner $\mathrm{TiO}_{2}$ photoanodes. To evaluate the performance of TPDO-based devices built with thinner $\mathrm{TiO}_{2}$ film ( $3 \mu$ m-thick $\mathrm{TiO}_{2} 20 \mathrm{~nm}$ nanoparticles + $6 \mu \mathrm{m}$ light-scattering $\mathrm{TiO}_{2}$ particles), three soaking methods have been compared: 1) Dipping in a pure solution of the dyes; 2) Dipping in a solution containing both dyes and CDCA; 3) Successive soaking in the dye solution and, then, in a CDCA bath.

The photovoltaic performances of the corresponding devices were still high for diphenylamino and amido donor substituents in the para position. Thus, for para-benzamide TPDO 5A and the same soaking method, the overall energy conversion yield remained unchanged $\left(J_{\mathrm{sc}}=8.44 \mathrm{mAcm}^{-2}, V_{\mathrm{oc}}=0.699 \mathrm{~V}\right.$, $f f=0.716, \eta=4.22 \%)$. The weaker current density, which could be due to the decrease of light absorption, was compensated by a higher open-circuit voltage. On the other hand, the photoconversion efficiency of our best dye $6 \mathrm{~A}$ obtained for thin film reached $4.61,4.54$, and $5.06 \%$, respectively, for soaking in the solution of the pure dyes, in a solution of both dye and CDCA, and in two baths as described above (Figure 7 and the 


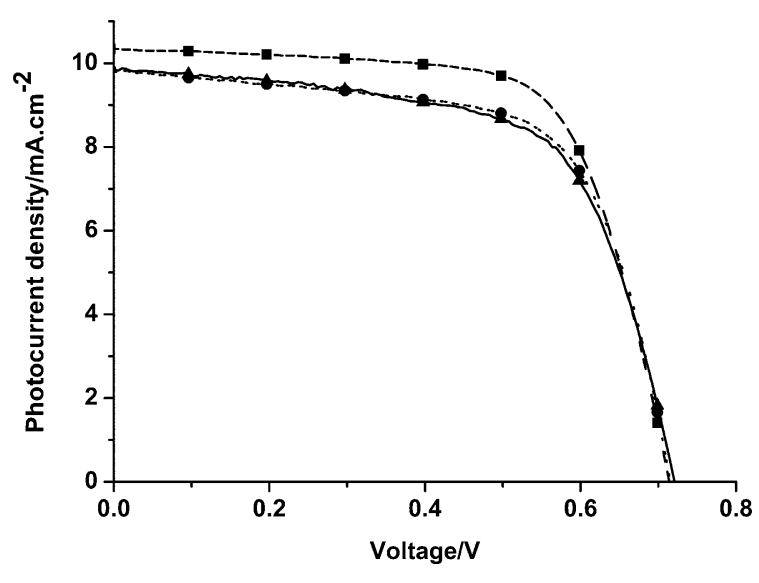

Figure 7. IN curves of DSCs made of $3 \mu \mathrm{m}$ thick nanoparticulate anatase $\mathrm{TiO}_{2}$ films sensitized with a pure solution of $6 \mathrm{~A}(\bullet . .$.$) , a solution of 6 \mathrm{~A}$ and CDCA ( $\triangle \quad$ ), by successive soak in a solution of $6 \mathrm{~A}$ and solution of CDCA ( $\quad)$.

Supporting Information). Although the part of aggregated dyes was greater without CDCA and contrary to what we observed for other dyes, the performances remained high.

\section{Conclusion}

An original and versatile route has been successfully established to synthesize nine new TPDOs possessing high solubility and unsymmetrical structures. This synthetic pathway allowed for controlling precisely the position isomerism as evidenced by X-ray diffraction of single crystals of TPDOs. Moreover, the molecular structure revealed the bending of the $\pi$-conjugated system, which was confirmed by modeling, due to the steric hindrance of two tert-butyl substituents. On the other hand, the TPDO derivatives covered a large part of the solar spectrum with strong molar extension coefficients while preserving the high photostability, commonly observed for TPDO pigments. The visible absorption band has been attributed to the charge transfer between the two external substituents, consistently with the push-pull structure of the dyes. Moreover, the HOMO and LUMO energy levels calculated at the DFT level and estimated from cyclic voltammetry were suitable for the integration of TPDO dye in DSC containing titanium oxide as transparent semiconductor and iodide/triiodide as redox shuttle. As a consequence, all these properties allowed us to integrate the TPDO core into DSC by soaking of porous $\mathrm{TiO}_{2}$ films with TPDO dye and co-adsorbent solutions. The best performances were obtained for para isomers and led to a maximum of $6.3 \%$ of photoconversion yield for dye $6 \mathrm{~A}$. Interestingly, the dye $\mathbf{5 A}$ bearing weaker push-pull substituents gave one of the best photocurrent of the series, indicating an efficient injection despite of the absence of strong electron-donating group. To take advantage of the high dye absorption and prepare the next generation of solid-state DSCs, devices were elaborated with $3 \mu \mathrm{m}$-thick thin oxide layer and without co-absorbent leading to only a slight decrease in performances.

Finally, this original synthetic route opens the way for the design of new TPDO derivatives. Moreover, their performances make them suitable candidates for liquid- or solid-sate DSSCs. A better understanding of the relationships between the molecular structure and the electronic processes involved in these systems should be obtained by means of transient absorption spectroscopy measurements performed onto sensitized titanium oxide films, which are currently in progress in our laboratories. These latter should provide additional information for optimizing the performances of the next generation of TPDO dyes.

\section{Experimental Section}

\section{Materials and general methods}

${ }^{1} \mathrm{H}$ and ${ }^{13} \mathrm{C}\left\{{ }^{1} \mathrm{H}\right\}$ NMR spectra were recorded on a DPX-300 spectrometer ( $\delta$ given in ppm relative to tetramethylsilane). Electrospray mass spectra (ESI-TOF HRMS) were carried out by the CESAMO (Bordeaux, France) on a Qstar Elite mass spectrometer (Applied Biosystems). The electrospray needle was operated at room temperature. Spectra were recorded in the positive-ion mode using the reflextron and with an accelerating voltage of $20 \mathrm{kV}$ (high resolution). Elemental microanalyses were performed at the CESAMO (Bordeaux, France). UV/Visible absorption studies have been carried out with a UV-1650PC SHIMADZU and Cary 5G (Varian) spectrophotometers. Steady-state emission spectra were recorded on Fluoro$\log$ (Jobin Yvon) spectrofluorimeter. Time-resolved fluorescence was measured with a streak camera Hamamatsu 5680 equipped with a fast single sweep unit M5676 (temporal resolution 2 ps) and coupled to a spectrograph (Chromex 250). The fluorescence excitation light pulses were obtained from Ti:Sapphire femtosecond laser system (Femtopower Compact Pro) followed by an optical parametric generator with frequency mixers (Topas C). The procedure to determine photodestruction quantum yields has been described elsewhere ${ }^{[27]}$ and consists in the measurement of absorption decay during irradiation of the solution at appropriate wavelength followed by a mathematical treatment of the obtained kinetic. Cyclic voltammetry studies were carried out with a potentiostat/galvanostat Autolab PGSTAT100 using a three-electrode device (working electrode: Pt disc; reference electrode: $\mathrm{Ag} / \mathrm{AgCl}$ calibrated with ferrocenium/ferrocene as the internal reference; counter electrode: Pt).

\section{Syntheses}

2,5-di-tert-butyl-3,6-bis(2-nitrophenoxy)-1,4-benzoquinone (13): Under an inert atmosphere, potassium nitrophenoxide $(1.51 \mathrm{~g}$, $8.52 \mathrm{mmol}$ ) was added to a solution of 2,5-di-tert-butyl-3,6-dichloro-1,4-benzoquinone $12(1.231 \mathrm{~g}, 4.26 \mathrm{mmol})$ in DMF $(10 \mathrm{~mL})$. After stirring at $100^{\circ} \mathrm{C}$ for $10 \mathrm{~h}$, the mixture was poured into chloroform $(50 \mathrm{~mL})$. Then, the organic phase was washed with $\mathrm{HCl}$ $1 \mathrm{~N}$ aqueous solution $(50 \mathrm{~mL})$ and $\mathrm{NaOH} 1 \mathrm{~N}$ aqueous solution $(50 \mathrm{~mL})$. After evaporation of the volatiles, the brown solid was successively rinsed with water, methanol, and pentane to give a yellow powder $(1.48 \mathrm{~g}, 70 \%) .{ }^{1} \mathrm{H}$ NMR $\left(400 \mathrm{MHz},\left[\mathrm{D}_{6}\right] \mathrm{DMSO}, 25^{\circ} \mathrm{C}\right.$, TMS): $\delta \quad 8.05\left(\mathrm{~d},{ }^{4} J(\mathrm{H}, \mathrm{H}) \quad 2 \mathrm{~Hz}, 1 \mathrm{H}\right), 8.17\left(\mathrm{dd},{ }^{3} \mathrm{~J}(\mathrm{H}, \mathrm{H}) \quad 8.1 \mathrm{~Hz}\right.$, $\left.{ }^{4} J(\mathrm{H}, \mathrm{H}) \quad 1.2 \mathrm{~Hz}, 2 \mathrm{H}\right), 7.64\left(\mathrm{t},{ }^{3} \mathrm{~J}(\mathrm{H}, \mathrm{H}) \quad 7.8 \mathrm{~Hz}, 2 \mathrm{H}\right), 7.40\left(\mathrm{~d},{ }^{3} \mathrm{~J}(\mathrm{H}, \mathrm{H})\right.$ $8.4 \mathrm{~Hz}, 2 \mathrm{H}), 7.29\left(\mathrm{t},{ }^{3} \mathrm{~J}(\mathrm{H}, \mathrm{H}) \quad 7.8 \mathrm{~Hz}, 2 \mathrm{H}\right), 1.24 \mathrm{ppm}(\mathrm{s}, 18 \mathrm{H})$; ${ }^{13} \mathrm{C}$ NMR $\quad\left(101 \mathrm{MHz}, \quad\left[\mathrm{D}_{6}\right] \mathrm{DMSO}, 25^{\circ} \mathrm{C}, \mathrm{TMS}\right): \delta 181.64,149.66$, $149.41,139.13,138.79,134.40,125.36,123.08,118.18,35.27$, 29.53 ppm; HRMS (ESI): $\mathrm{m} / \mathrm{z}$ calcd for $\mathrm{C}_{26} \mathrm{H}_{26} \mathrm{~N}_{2} \mathrm{O}_{8}+\mathrm{Na}^{+}: 517.1581$ $\left[M+\mathrm{Na}^{+}\right]$; found: 517.1598 . 
6,13-Di-tert-butyltriphenodioxazine (10): In a 2-necked roundbottom flask containing a stir bar, the compound 13 (550 mg, $1.11 \mathrm{mmol}), \mathrm{Fe}(3.10 \mathrm{~g}, 55.5 \mathrm{mmol}), \operatorname{THF}(15 \mathrm{~mL})$, and AcOH $(15 \mathrm{~mL})$ was heated at reflux during $1.5 \mathrm{~h}$. Then, the mixture was filtered and rinsed with chloroform $(30 \mathrm{~mL})$ to remove the excess of iron. After addition of chloranil $(2.72 \mathrm{~g}, 11.1 \mathrm{mmol})$ and stirring overnight, the organic phase was washed with water and $2 \% \mathrm{Na}_{2} \mathrm{CO}_{3}$ aqueous solution, dried over $\mathrm{MgSO}_{4}$ and concentrated. The crude material was purified by column chromatography over silica gel (petroleum ether/chloroform 9:1) and isolated as a red powder (195 mg, 44\%). ${ }^{1} \mathrm{H}$ NMR (400 MHz, $\mathrm{CDCl}_{3}, 25^{\circ} \mathrm{C}$, TMS) $\delta 7.42$ (dd, $\left.{ }^{3} J(\mathrm{H}, \mathrm{H}) \quad 7.7 \mathrm{~Hz},{ }^{4} J(\mathrm{H}, \mathrm{H}) \quad 1.6 \mathrm{~Hz}, \quad 2 \mathrm{H}\right), 7.17 \quad\left(\mathrm{td},{ }^{3} \mathrm{~J}(\mathrm{H}, \mathrm{H}) \quad 7.7 \mathrm{~Hz}\right.$ $\left.{ }^{4} J(\mathrm{H}, \mathrm{H}) \quad 1.6 \mathrm{~Hz}, 2 \mathrm{H}\right), 7.10\left(\mathrm{td},{ }^{3} J(\mathrm{H}, \mathrm{H}) \quad 7.6 \mathrm{~Hz},{ }^{4} J(\mathrm{H}, \mathrm{H}) \quad 1.4 \mathrm{~Hz}, 2 \mathrm{H}\right)$, $7.02\left(\mathrm{dd},{ }^{3} \mathrm{~J}(\mathrm{H}, \mathrm{H}) \quad 7.9 \mathrm{~Hz},{ }^{4} J(\mathrm{H}, \mathrm{H}) \quad 1.3 \mathrm{~Hz}, 2 \mathrm{H}\right), 1.64 \mathrm{ppm}(\mathrm{s}, 18 \mathrm{H})$; ${ }^{13} \mathrm{C} \mathrm{NMR}\left(101 \mathrm{MHz}, \mathrm{CDCl}_{3}, 25^{\circ} \mathrm{C}\right.$, TMS) $\delta 151.16,144.28,143.81$, 133.33, 128.50, 127.94, 124.28, 122.39, 114.60, 37.07, 31.90 ppm; HRMS (ESI): $\mathrm{m} / \mathrm{z}$ calcd for $\mathrm{C}_{26} \mathrm{H}_{26} \mathrm{~N}_{2} \mathrm{O}_{2}+\mathrm{H}^{+}: 399.20725\left[\mathrm{M}+\mathrm{H}^{+}\right]$; found: 399.2075

Methyl 1,4-di-tert-butyl-2-chloro-3-oxo-3H-phenoxazine-7-carboxylate (15): Sodium bicarbonate $(14.5 \mathrm{~g}, 0.173 \mathrm{~mol})$ was added to a solution of methyl 4-amino-3-hydroxybenzoate $(17.3 \mathrm{mmol})$ and 2,5-di-tert-butyl-3,6-dichloro-1,4-benzoquinone $12 \quad(5 \mathrm{~g}$, $17.3 \mathrm{mmol}$ ) in dimethylacetamide under nitrogen. The reaction mixture was stirred at $80^{\circ} \mathrm{C}$ overnight. Then, hydrochloric acid $1 \mathrm{M}$ $(100 \mathrm{~mL})$ was added carefully and the product was extracted into ethyl acetate $(3 \times 100 \mathrm{~mL})$. The organic phase was then washed with brine, dried over $\mathrm{MgSO}_{4}$ and the solvent was evaporated. Then, the product was purified by column chromatography over silica gel (petroleum ether/ethyl acetate $95: 5$ ) to be isolated as an orange powder $(5 \mathrm{~g}, 76 \%)$. ${ }^{1} \mathrm{H}$ NMR $\left(200 \mathrm{MHz}, \mathrm{CDCl}_{3}, 25^{\circ} \mathrm{C}\right.$, TMS): $\delta \quad 8.41\left(\mathrm{~d},{ }^{4} J(\mathrm{H}, \mathrm{H}) \quad 2 \mathrm{~Hz}, 1 \mathrm{H}\right), 8.17\left(\mathrm{dd},{ }^{3} J(\mathrm{H}, \mathrm{H}) \quad 8.6 \mathrm{~Hz},{ }^{4} J(\mathrm{H}, \mathrm{H})\right.$ $2 \mathrm{~Hz}, 1 \mathrm{H}), 7.33\left(\mathrm{~d},{ }^{3} \mathrm{~J}(\mathrm{H}, \mathrm{H}) \quad 8.6 \mathrm{~Hz}, 1 \mathrm{H}\right), 4.00(\mathrm{~s}, 3 \mathrm{H}), 1.72(\mathrm{~s}, 9 \mathrm{H})$, $1.53 \mathrm{ppm}(\mathrm{s}, 9 \mathrm{H}) ;{ }^{13} \mathrm{C}$ NMR $\left(75 \mathrm{MHz}, \mathrm{CDCl}_{3}, 25^{\circ} \mathrm{C}\right.$, TMS): $\delta \quad 178.38$, $165.68,150.64,146.74,145.10,142.66,140.01,133.72,132.68$, $129.48,125.89,125.84,116.71,52.83,39.63,36.13,32.17$, 30.60 ppm; HRMS (ESI): $\mathrm{m} / z$ calcd for $\mathrm{C}_{22} \mathrm{H}_{24} \mathrm{ClNO}_{4}+\mathrm{H}^{+}: 402.1472$ $\left[\mathrm{M}+\mathrm{H}^{+}\right]$; found: 402.1469; elemental analysis calcd (\%) for $\mathrm{C}_{22} \mathrm{H}_{24} \mathrm{ClNO}_{4}$ : C 65.75, H 6.02, N 3.49, Cl 8.82; found: $\mathrm{C}, 65.88, \mathrm{H}$, $6.04 ; \mathrm{N}, 3.32 ; \mathrm{Cl}, 9.19$.

Methyl 2-(4-bromo-2-nitrophenoxy)-1,4-di-tert-butyl-3-oxo-3Hphenoxazine-7-carboxylate (16): Potassium tert-butoxide $(2.46 \mathrm{~g}$, $22 \mathrm{mmol}$ ) was added to a solution of 5-bromo-2-nitrophenol $(20 \mathrm{mmol})$ in dimethylacetamide $(80 \mathrm{~mL})$ under nitrogen. The reaction mixture was stirred at RT for $1 \mathrm{~h}$ and a red solid precipitated. Then, phenoxazine $15(4.02 \mathrm{~g}, 10 \mathrm{mmol})$ was added and the reaction mixture was stirred at $80^{\circ} \mathrm{C}$ during $48 \mathrm{~h}$. After addition of $\mathrm{HCl}$ $1 \mathrm{M}(100 \mathrm{~mL})$, the product was extracted into ethyl acetate. The organic phase was washed with brine, dried over $\mathrm{MgSO}_{4}$ and the solvent was evaporated. Finally, the product was purified by column chromatography over silica gel (petroleum ether/ethyl acetate 95:5) and isolated as a light-red powder $(2.60 \mathrm{~g}, 42 \%)$. ${ }^{1} \mathrm{H}$ NMR (200 MHz, CDCl $3,25^{\circ} \mathrm{C}$, TMS): $\delta \quad 8.04\left(\mathrm{dd},{ }^{3} J(\mathrm{H}, \mathrm{H}) \quad 7.8 \mathrm{~Hz},{ }^{4} J(\mathrm{H}, \mathrm{H})\right.$ $1.6 \mathrm{~Hz}, 1 \mathrm{H}), 7.99\left(\mathrm{~d},{ }^{4} J(\mathrm{H}, \mathrm{H}) \quad 1.6 \mathrm{~Hz}, 1 \mathrm{H}\right), 7.95\left(\mathrm{~d},{ }^{3} J(\mathrm{H}, \mathrm{H}) \quad 9.0 \mathrm{~Hz}\right.$, $1 \mathrm{H}), \quad 7.86\left(\mathrm{~d},{ }^{3} J(\mathrm{H}, \mathrm{H}) \quad 7.8 \mathrm{~Hz}, \quad 1 \mathrm{H}\right), \quad 7.27\left(\mathrm{dd},{ }^{3} J(\mathrm{H}, \mathrm{H}) \quad 9.0 \mathrm{~Hz}\right.$, $\left.{ }^{4} J(\mathrm{H}, \mathrm{H}) \quad 2.0 \mathrm{~Hz}, 1 \mathrm{H}\right), 6.86\left(\mathrm{~d},{ }^{4} \mathrm{~J}(\mathrm{H}, \mathrm{H}) \quad 2.0 \mathrm{~Hz}, 1 \mathrm{H}\right), 4.02(\mathrm{~s}, 3 \mathrm{H}), 1.65$ $(\mathrm{s}, 9 \mathrm{H}), 1.64 \mathrm{ppm}(\mathrm{s}, 9 \mathrm{H}) ;{ }^{13} \mathrm{C} \mathrm{NMR}\left(101 \mathrm{MHz}, \mathrm{CDCl}_{3}, 25^{\circ} \mathrm{C}, \mathrm{TMS}\right) \delta$ $178.36,165.62,151.86,150.24,148.46,145.56,142.36,138.43$, $137.83,133.82,133.02,129.60,128.42,127.55,126.02,125.36$, $120.42,116.84,77.16,52.88,37.85,36.10,32.09,30.55$ ppm; HRMS (ESI): $\mathrm{m} / \mathrm{z}$ elemental analysis calcd (\%) for $\mathrm{C}_{28} \mathrm{H}_{27} \mathrm{BrN}_{2} \mathrm{O}_{7}+\mathrm{H}^{+}$: $583.1080\left[\mathrm{M}+\mathrm{H}^{+}\right]$; found 583.1100 .

Methyl 3-bromo-6,13-di-tert-butyltriphenodioxazine-10-carboxylate (1 E): Sodium dithionite $(5.92 \mathrm{~g}, 34 \mathrm{mmol})$ was added to a so- lution of the phenoxazine $16(1.7 \mathrm{mmol})$ in a mixture ethanol/ water 4:1 $(50 \mathrm{~mL})$. The reaction mixture was heated at reflux overnight. Then, $\mathrm{HCl} 1 \mathrm{M}(100 \mathrm{~mL})$ was added and the product was extracted into ethyl acetate. The organic phase was washed with brine, dried over $\mathrm{MgSO}_{4}$ and the solvent was evaporated. The crude material was dissolved in chloroform $(50 \mathrm{~mL})$ and chloranil $(4.19 \mathrm{~g}, 17 \mathrm{mmol})$ was added. The reaction mixture was stirred at RT overnight. Then, $\mathrm{HCl} 1 \mathrm{M}(50 \mathrm{~mL})$ was added, the two phases were separated, and the product was extracted into chloroform. The organic phase was washed with water, dried over $\mathrm{MgSO}_{4}$ and the solvent was evaporated. The product was purified by column chromatography over silica gel (petroleum ether/chloroform 95:5) and isolated as a deep-red powder $(46 \%){ }^{1} \mathrm{H}$ NMR $\left(200 \mathrm{MHz}, \mathrm{CDCl}_{3}\right.$, $\left.25^{\circ} \mathrm{C}, \mathrm{TMS}\right): \delta \quad 7.80\left(\mathrm{dd},{ }^{3} J(\mathrm{H}, \mathrm{H}) \quad 8.0 \mathrm{~Hz},{ }^{4} J(\mathrm{H}, \mathrm{H}) \quad 1.6 \mathrm{~Hz}, 1 \mathrm{H}\right), 7.69$ (d, $\left.{ }^{4} J(\mathrm{H}, \mathrm{H}) \quad 1.6 \mathrm{~Hz}, 1 \mathrm{H}\right), 7.46\left(\mathrm{~d},{ }^{3} \mathrm{~J}(\mathrm{H}, \mathrm{H}) \quad 8.0 \mathrm{~Hz}, 1 \mathrm{H}\right), 7.30(\mathrm{~m}, 3 \mathrm{H})$, $3.96(\mathrm{~s}, 3 \mathrm{H}), 1.65(\mathrm{~s}, 9 \mathrm{H}), 1.64 \mathrm{ppm}(\mathrm{s}, 9 \mathrm{H}) ;{ }^{13} \mathrm{C} \mathrm{NMR}\left(75 \mathrm{MHz}, \mathrm{CDCl}_{3}\right.$, $25^{\circ} \mathrm{C}$, TMS): $\delta$ 166.21, 152.77, 150.85, 144.17, 144.08, 143.88, $143.34,136.73,132.29,129.61,129.05,127.83,127.64,125.77$, 123.27, 123.11，121.62, 117.94, 115.93, 52.49, 37.17, 31.89, $31.83 \mathrm{ppm}$; HRMS (ESI): $\mathrm{m} / \mathrm{z}$ calcd (\%) for $\mathrm{C}_{28} \mathrm{H}_{27} \mathrm{BrN}_{2} \mathrm{O}_{7}+\mathrm{H}^{+}$: $535.1232\left[\mathrm{M}+\mathrm{H}^{+}\right]$; found: 535.1203 .

Methyl 6,13-di-tert-butyl-3-diphenylaminotriphenodioxazine-10carboxylate (6E): Brominated derivative 1E $(100 \mathrm{mg}, 0.187 \mathrm{mmol})$ and the sodium tert-butoxide $(20 \mathrm{mg}, 0.21 \mathrm{mmol}$ ) was added to a solution of the diphenylamine $\left.(0.187 \mathrm{mmol}), \mathrm{Pd}_{2}(\mathrm{dba})_{3}\right](6.8 \mathrm{mg}$, $7.5 \mu \mathrm{mol}$; dba tris(dibenzylideneacetone)) and diphenylphosphine ferrocene $(8.3 \mathrm{mg}, 15 \mu \mathrm{mol})$ in toluene $(30 \mathrm{~mL})$ under nitrogen. The reaction mixture was then stirred at reflux during $3 \mathrm{~h}$; it turned dark purple. Then, hydrochloric acid $1 \mathrm{~m}(50 \mathrm{~mL})$ was added. The product was extracted into ethyl acetate $(2 \times 100 \mathrm{~mL})$ and the organic phase was washed with brine, dried over $\mathrm{MgSO}_{4}$ and the solvent was evaporated. Then, the product was purified by column chromatography over silica gel (petroleum ether/ethyl acetate $90: 10)$ to yield a purple powder (43\%). ${ }^{1} \mathrm{H}$ NMR $\left(300 \mathrm{MHz}, \mathrm{CDCl}_{3}\right.$, TMS): $\delta \quad 7.78\left(\mathrm{dd},{ }^{3} J(\mathrm{H}, \mathrm{H}) \quad 8.4 \mathrm{~Hz},{ }^{4} J(\mathrm{H}, \mathrm{H}) \quad 1.8 \mathrm{~Hz}, 1 \mathrm{H}\right), 7.66(\mathrm{~d}$, $\left.{ }^{4} J(\mathrm{H}, \mathrm{H}) \quad 1.8 \mathrm{~Hz}, 1 \mathrm{H}\right), 7.36(\mathrm{~m}, 7 \mathrm{H}), 7.18(\mathrm{~m}, 7 \mathrm{H}), 6.84\left(\mathrm{dd},{ }^{3} J(\mathrm{H}, \mathrm{H})\right.$ $\left.8.7 \mathrm{~Hz},{ }^{4} J(\mathrm{H}, \mathrm{H}) \quad 2.4 \mathrm{~Hz}, 1 \mathrm{H}\right), 6.74\left(\mathrm{~d},{ }^{4} J(\mathrm{H}, \mathrm{H}) 2.4 \mathrm{~Hz}, 1 \mathrm{H}\right), 3.97(\mathrm{~s}$, $3 \mathrm{H}), 1.69(\mathrm{~s}, 9 \mathrm{H}), 1.62 \mathrm{ppm}(\mathrm{s}, 9 \mathrm{H}) ;{ }^{13} \mathrm{C}$ NMR $\left(101 \mathrm{MHz}, \mathrm{CD}_{2} \mathrm{Cl}_{2}\right.$ TMS): $\delta$ 166.59, 153.81, 149.52, 148.50, 147.41, 145.35, 144.90, $144.16,144.09,137.77,130.08,129.43,128.95,128.87,127.40$, $125.94,124.76,123.75,122.55,119.33,115.99,107.35,52.65,37.49$, 37.31, 32.20, 31.96 ppm; IR (ATR): $\tilde{v}$ 2954, 1723, 1625, 1596, $1290 \mathrm{~cm}^{1}$; HRMS (ESI): $\mathrm{m} / \mathrm{z}$ calcd for $\mathrm{C}_{40} \mathrm{H}_{38} \mathrm{~N}_{3} \mathrm{O}_{4}+\mathrm{H}^{+}: 624.28623$ $\left[M+\mathrm{H}^{+}\right]$; found: 624.2846 .

6,13-Di-tert-butyl-3-diphenylaminotriphenodioxazine-10-carboxylic acid (6A): $\mathrm{KOH}$ (10 equiv) and a solution of tetrabutylammonium fluoride $1 \mathrm{M}$ in THF $(0.1 \mathrm{~mL})$ was added to a solution of the ester derivative $6 \mathrm{E}$ in toluene. The reaction mixture was heated at reflux for $4 \mathrm{~h}$. Then, $\mathrm{HCl} 1 \mathrm{M}(50 \mathrm{~mL})$ was added and the product was extracted into ethyl acetate $(3 \times 50 \mathrm{~mL})$. The organic phase was washed with saturated $\mathrm{NaCl}$ (aq., $100 \mathrm{~mL}$ ), dried over $\mathrm{MgSO}_{4}$ and the solvent was evaporated. Then, the product was purified by column chromatography over silica gel firstly gradient-eluted with petroleum ether/ethyl acetate (from 90:10 to 0:100) and secondly with ethyl acetate/methanol (80:20). Then, the product was dissolved in methanol $(50 \mathrm{~mL})$ with $\mathrm{KOH}(5 \mathrm{~g})$. The mixture was filtered, water was added $(20 \mathrm{~mL})$ and the methanol was evaporated. Concentrated $\mathrm{HCl}$ was added to the solution until complete precipitation of the acid $(\mathrm{pH} \approx 1)$. Then, the pure acid was filtered washed with distilled water and dried under vacuum to lead to a purple powder (45\%). ${ }^{1} \mathrm{H}$ NMR $\left(300 \mathrm{MHz},\left[\mathrm{D}_{8}\right] \mathrm{THF}, \mathrm{TMS}\right): \delta 7.74$ $\left(\mathrm{d},{ }^{3} \mathrm{~J}(\mathrm{H}, \mathrm{H}) \quad 8.1 \mathrm{~Hz}, 1 \mathrm{H}\right), 7.61(\mathrm{~s}, 1 \mathrm{H}), 7.33(\mathrm{~m} \mathrm{6H}), 7.12(\mathrm{~m}, 6 \mathrm{H})$ $6.80\left(\mathrm{dd},{ }^{3} J(H, H) \quad 8.7 \mathrm{~Hz},{ }^{4} J(\mathrm{H}, \mathrm{H}) \quad 2.1 \mathrm{~Hz}, 1 \mathrm{H}\right), 6.69\left(\mathrm{~d},{ }^{4} J(\mathrm{H}, \mathrm{H})\right.$ 
$2.1 \mathrm{~Hz}, 1 \mathrm{H}), 1.67(\mathrm{~s}, 9 \mathrm{H}), 1.58 \mathrm{ppm}(\mathrm{s}, 9 \mathrm{H}) ;{ }^{13} \mathrm{C} \mathrm{NMR}(400 \mathrm{MHz}$ $\left.\left[\mathrm{D}_{8}\right] \mathrm{THF}, \mathrm{TMS}\right): \delta 163.8,153.8,150.3,149.0,148.1,148.0,145.8$, $145.4,144.8,144.5,137.7,130.5,129.6,129.4,127.8,126.8,126.4$, $125.2,124.0,122.9,120.0,116.5,107.9,38.0,37.8,32.5,32.3$ ppm; HRMS (ESI): $m / z$ elemental analysis calcd (\%) for $\mathrm{C}_{39} \mathrm{H}_{36} \mathrm{~N}_{3} \mathrm{O}_{4}+\mathrm{H}^{+}$: $610.27058\left[\mathrm{M}+\mathrm{H}^{+}\right]$; found: 610.27040 .

Caution: Excess chloranil is difficult to remove. The following extra procedure allows the total removal of chloranil. The impure material was dissolved in ether. Then, a small amount of diethylamine was added that reacted with chloranil. After stirring for $15 \mathrm{~min}$, the product was eluted on a small column chromatography over silica gel by the solvent mixture described in procedure.

\section{Quantum chemical calculations}

Molecular geometries were optimized at the density functional theory (DFT) level using the B3LYP exchange-correlation (XC) functional and the $631+G(d, p)$ basis set. The absorption properties of the dyes were calculated using the time-dependent DFT (TD-DFT) method with the $6311 \mathrm{~g}(\mathrm{~d})$ basis set and the MPW1K XC functional. ${ }^{[28]}$ This hybrid functional, which contains $42.8 \%$ of Hartree Fock (HF) exchange, has been shown to provide absorption spectra in good agreement with experiments for other push pull organic systems. ${ }^{[29]}$ To obtain an accurate description of the photoinduced charge transfer (CT) phenomena along the dyes, we also performed TD-DFT calculations using the long-range corrected $\omega$ B97X-D functional, in which the amount of HF exchange increases with the inter-electron distance $(22.20 \%$ of HF exchange at shortrange and $77.80 \%$ at long-range, with a range separation parameter of 0.20). ${ }^{[30]}$ Moreover, additional calculations performed using the $6311 \mathrm{~g}(\mathrm{~d})$ basis set demonstrated that the absorption properties are not significantly affected by the addition of diffuse functions (see the Supporting Information). Solvent effects (dichloromethane) were included both in geometry optimizations and TD-DFT calculations by using the polarizable continuum model in its integral equation formalism (IEF-PCM) ${ }^{[31]}$ All calculations were performed with Gaussian 09. ${ }^{[32]}$

\section{Device fabrication and characterization}

FTO-coated conducting glass substrates (NSG10, 10 ohm/square, glass thickness $3.2 \mathrm{~mm}$, XOPFisica) were cleaned in ethanol followed by an ultrasonic treatment in an alkaline detergent solution. The conducting glass was then treated under $\mathrm{UV} / \mathrm{O}_{3}$ during $20 \mathrm{~min}$ to remove the remaining carbon residues. To increase photoanode adhesion while reducing recombination between TCO and $\mathrm{I}_{3}$ at this interface, the conducting glass was then treated by a $40 \mathrm{~mm}$ $\mathrm{TiCl}_{4}$ aqueous solution at $70^{\circ} \mathrm{C}$ for $30 \mathrm{~min}$. The photoanode was prepared by using the screen-printing method using commercially available titania pastes. First a transparent layer was deposited. This layer was composed of $20 \mathrm{~nm}$-based anatase $\mathrm{TiO}_{2}$ particles (Dyesol DSL90-T) and was reaching a thickness of $10 \mu \mathrm{m}$. A second layer of around $5 \mu \mathrm{m}$ thick was printed afterwards. The role of this scattering layer, constituted of $150250 \mathrm{~nm}$-based $\mathrm{TiO}_{2}$ particles (Dyesol WER2-O), was to backscatter the unabsorbed photons towards the transparent layer. Ethyl-cellulose and terpineol contained in the titania pastes were removed by gradual thermal treatment under air flow at $325(5 \mathrm{~min}), 375(5 \mathrm{~min}), 450(15 \mathrm{~min})$, and $500^{\circ} \mathrm{C}$ (15 min). The as-obtained films were further treated with a $\mathrm{TiCl}_{4}$ aqueous solution $(40 \mathrm{~mm})$ at $70^{\circ} \mathrm{C}$ for $30 \mathrm{~min}$ and again heated at $500^{\circ} \mathrm{C}$ for $30 \mathrm{~min}$. After cooling to $\approx 60^{\circ} \mathrm{C}$, the electrodes were immersed in $0.3 \mathrm{mM}$ dye solutions $\left(\mathrm{CH}_{2} \mathrm{Cl}_{2}\right)$ containing an optimized $2 \mathrm{~mm}$ concentration of cheno-deoxycholic acid, playing both the role of co-adsorbent and de-aggregating agent. The sensitization time was optimized to $5 \mathrm{~h}$ in dark. The dye-modified $\mathrm{TiO}_{2}$ photoanodes were then assembled with a platinum counter electrode using a hot-melt Surlyn polymer gasket and the iodine-based electrolyte (EL-HPE, DyeSol) was introduced in the cell by vacuum back-filling as previously described. ${ }^{[30]}$ The as-obtained cells (working area $0.159 \mathrm{~cm}^{2}$ defined using a black mask) were then illuminated by AM1.5G solar simulator calibrated with a radiometer (IL $1400 \mathrm{BL}$ ) to provide an incident irradiance of $100 \mathrm{~mW} \mathrm{~cm}{ }^{2}$ and the $I / V$ responses were measured by using a Keithley model 2400 digital source meter (Keithley). The incident photon-to-charge carrier efficiency (IPCE) data were collected from 300 to $1000 \mathrm{~nm}$ by using a Xe lamp associated with a monochromator (Triax 180, Jobin Yvon). A Bias light was employed to illuminate the cell to reach $10 \%$ of $J_{\text {sc. }}$. The current produced was measured by steps of $1 \mathrm{~nm}$ after $0.2 \mathrm{~s}$ of radiation exposure with a Keithley 6487 picoammeter to be in steady-state conditions. The incident photon flux was measured with a 6-inch diameter calibrated integrated sphere (Labsphere) and a silicon detector.

\section{Acknowledgements}

This work was supported by the GIS AMA (Advanced Materials in Aquitaine) and the ANR ("FMOCSOLE" ANR-BLAN-201093801). Calculations were carried out on mainframe computers of the "Mésocentre de Calcul Intensif Aquitain" (MCIA) of the University of Bordeaux, funded by the Conseil Régional d'Aquitaine and the French Ministry of Research and Technology.

Keywords: dyes/pigments - donor-acceptor systems . photostability $\cdot$ solar cells $\cdot$ synthetic methods

[1] a) P. M. Beaujuge, J. M. J. Fréchet, J. Am. Chem. Soc. 2011, 133, 20009 20029; b) T. M. Figueira Duarte, K. Müllen, Chem. Rev. 2011, 111, 7260 7314

[2] P. M. Beaujuge, C. M. Amb, J. R. Reynolds, Acc. Chem. Res. 2010, 43, 13961407.

[3] a) C. Wang, H. Dong, W. Hu, Y. Liu, D. Zhu, Chem. Rev. 2012, 112, 2208 2267; b) M. Mas Torrent, C. Rovira, Chem. Rev. 2011, 111, 48334856.

[4] X. Zhan, A. Facchetti, S. Barlow, T. J. Marks, M. a. Ratner, M. R. Wasielew ski, S. R. Marder, Adv. Mater. 2011, 23, 268284.

[5] M. J. Robb, S. Y. Ku, F. G. Brunetti, C. J. Hawker, J. Polym. Sci. Part A 2013, 51, 12631271.

[6] a) S. Qu, H. Tian, Chem. Commun. 2012, 48, 3039 3051; b) H. Bronstein, Z. Chen, R. S. Ashraf, W. Zhang, J. Du, J.R. Durrant, P. S. Tuladhar, K. Song, S. E. Watkins, Y. Geerts, M. M. Wienk, R. a J. Janssen, T. Anthopou los, H. Sirringhaus, M. Heeney, I. McCulloch, J. Am. Chem. Soc. 2011, 133, 32723275 ; c) E. Wang, Z. Ma, Z. Zhang, K. Vandewal, P. Henriksson, O. Inganäs, F. Zhang, M. R. Andersson, J. Am. Chem. Soc. 2011, 133, 14244 14247.

[7] a) R. Schmidt, J. H. Oh, Y. S. Sun, M. Deppisch, A. M. Krause, K. Radacki, H. Braunschweig, M. Könemann, P. Erk, Z. Bao, F. Würthner, J. Am. Chem. Soc. 2009, 131, 6215 6228; b) C. Piliego, D. Jarzab, G. Gigli, Z. Chen, A. Facchetti, M. A. Loi, Adv. Mater. 2009, 21, 1573 1576; c) B. a. Jones, A. Facchetti, M. R. Wasielewski, T. J. Marks, J. Am. Chem. Soc. 2007, 129, 15259 15278; d) D. K. Hwang, R. R. Dasari, M. Fenoll, V. Alain Rizzo, A. Dindar, J. W. Shim, N. Deb, C. Fuentes Hernandez, S. Barlow, D. G. Buck nall, P. Audebert, S. R. Marder, B. Kippelen, Adv. Mater. 2012, 24, 4445 4450.

[8] a) S. Qu, C. Qin, A. Islam, Y. Wu, W. Zhu, J. Hua, H. Tian, L. Han, Chem. Commun. 2012, 48, 6972 6974; b) T. Edvinsson, C. Li, N. Pschirer, J. Schoneboom, F. Eickemeyer, R. Sens, G. Boschloo, A. Herrmann, K. Mullen, A. Hagfeldt, J. Phys. Chem. C 2007, 111, 15137 15140; c) C. Li, J. H. Yum, S. J. Moon, A. Herrmann, F. Eickemeyer, N. G. Pschirer, P. Erk, J. Schoeboom, K. Mullen, M. Grätzel, M. K. Nazeeruddin, ChemSusChem 
2008, 1, 615 318; d) W. Ying, F. Guo, J. Li, Q. Zhang, W. Wu, H. Tian, J. Hua, ACS Appl. Mater. Interfaces 2012, 4, 4215 4224; e) F. Zhang, K. J. Jiang, J. H. Huang, C. C. Yu, S. G. Li, M. G. Chen, L. M. Yang, Y. L. Song, J. Mater. Chem. A 2013, 1, 48584863.

[9] a) A. Mishra, M. K. R. Fisher, P. Bäuerle, Angew. Chem. 2009, 121, 2510 2536; Angew. Chem. Int. Ed. 2009, 48, 2474 2510; b) Y. Ooyama, Y. Harima, ChemPhysChem 2012, 13, 4032 4064; c) M. Liang, J. Chen, Chem. Soc. Rev. 2013, 42, 34533488.

[10] Y. Wu, W. Zhu, Chem. Soc. Rev. 2013, 42, 20392058.

[11] a) E. B. Faulkner, R. J. Schwartz, T. Chamberlain in High Performance Pig ments, Wiley VCH, Weinheim, 2009, pp. 195 204; b) G. Fischer, J. Prakt. Chem. 1879, 19, 317 321; c) R. L. Mital, S. K. Jain, J. Chem. Soc. C 1971, 18751878.

[12] a) C. Di, J. Li, G. Yu, Y. Xiao, Y. Guo, Y. Liu, X. Qian, D. Zhu, Org. Lett 2008, 10, 3025 3028; b) Y. Nicolas, F. Castet, M. Devynck, P. Tardy, L. Hirsch, C. Labrugère, H. Allouchi, T. Toupance, Org. Electron. 2012, 13, 13921400

[13] T. Tanaka, T. Ashida, S. Matsumoto, Chem. Lett. 2011, 40, 573575.

[14] F. Qiao, A. Liu, Y. Xiao, Y. P. Ou, J. Q. Zhang, Y. C. Sang, Microelectron. J. 2008, 39, 15681571.

[15] a) K. M. Karlsson, X. Jiang, S. K. Eriksson, E. Gabrielsson, H. Rensmo, A. Hagfeldt, L. Sun, Chem. Eur. J. 2011, 17, 6415 6424; b) H. Tian, I. Bora, X. Jiang, E. Gabrielsson, K. M. Karlsson, A. Hagfeldt, L. Sun, J. Mater Chem. 2011, 21, 12462 12472; c) H. Tian, X. Yang, J. Cong, R. Chen, J. Liu, Y. Hao, A. Hagfeldt, L. Sun, Chem. Commun. 2009, 6288 6290; d) M. Karlsson, L. Yang, M. K. Karlsson, L. Sun, G. Boschloo, A. Hagfeldt, J. Pho tochem. Photobiol. A 2012, 239, 55 59; e) Y. Shan, J. Tang, H. Lai, H. Tan X. Liu, F. Yang, Q. Fang, Chin. J. Chem. 2012, 30, 1497 1503; f) Y. Hong, J. Y. Liao, D. Cao, X. Zang, D. B. Kuang, L. Wang, H. Meier, C. Y. Su, J. Org. Chem. 2011, 76, 80158021.

[16] M. Schaffroth, B. D. Lindner, V. Vasilenko, F. Rominger, U. H. F. Bunz, J. Org. Chem. 2013, 78, 31423150.

[17] D. Döpp, S. Neubauer, ARKIVOC (Gainesville, FL, US) 2001, 6266.

[18] M. NajeebUllah, D. W. Knight, M. A. Munawar, M. Yaseen, F. Vincenzo, Tetrahedron 2010, 66, 67616764.

[19] a) J. Yin, S. L. Buchwald, J. Am. Chem. Soc. 2002, 124, 60436048 b) W. C. Shakespeare, Tetrahedron Lett. 1999, 40, 2035 2038; c) J. S Yang, C. Y. Hwang, C. C. Hsieh, S. Y. Chiou, J. Org. Chem. 2004, 69, 719 726; d) J. P. Wolfe, S. L. Buchwald, J. Org. Chem. 2000, 65, 1144 1157; e) T. Yamamoto, M. Nishiyama, Y. Koie, Tetrahedron Lett. 1998, 39, 2367 2370.

[20] P. Meallier, S. Guittonneau, C. Emmelin, T. Konstantinova, Dyes Pigm. 1999, 40, 95.
[21] A. Hagfeldt, G. Boschloo, L. Sun, L. Kloo, H. Pettersson, Chem. Rev. 2010 $110,65956663$.

[22] a) T. Le Bahers, C. Adamo, I. Ciofini, J. Chem. Theory Comput. 2011, 7 , 2498 2506; b) D. Jacquemin, T. Le Bahers, C. Adamo, I. Ciofini, Phys. Chem. Chem. Phys. 2012, 14, 53835388.

[23] M. J. G. Peach, P. Benfield, T. Helgaker, D. J. Tozer, J. Chem. Phys. 2008, $128,044118$.

[24] D. Shi, Y. Cao, N. Pootrakulchote, Z. Yi, M. Xu, S. M. Zakeeruddin, M. Grätzel, J. Phys. Chem. C 2008, 112, 1747817485.

[25] a) S. M. Feldt, E. A. Gabrielsson, L. Sun, G. Boschloo, A. Hagfeldt, J. Am. Chem. Soc. 2010, 132, 16714 16724; b) A. Yella, H. W. Lee, H. N. Tsao, C. Yi, A. K. Chandiran, Md. K. Nazeeruddin, E. W G. Diau, C. Y. Yeh, S. M. Za keeruddin, M. Grätzel, Science 2011, 334, 629 634; c) L. Ducasse, F. Castet, R. Méreau, S. Nénon, J. Idé, T. Toupance, C. Olivier, Chem. Phys. Lett. 2013, 556, 151157.

[26] a) M. Wang, J. Liu, N. L. Cevey Ha, S. J. Moon, P. Liska, R. Humphry Baker, J. E. Moser, C. Grätzel, P. Wang, S. M. Zakeeruddin, M. Grätzel, Nano Today 2010, 5, 169 174; b) J. Burschka, A. Dualeh, F. Kessler, E. Baranoff, N. L. Cevey Ha, C. Yi, M. K. Nazeeruddin, M. Grätzel, J. Am. Chem. Soc 2011, 133, 1804218045.

[27] G. Vives, C. Giansante, R. Bofinger, G. Raffy, A. Del Guerzo, B. Kauffmann, P. Batat, G. Jonusauskas, N. D. McClenaghan, Chem. Commun. 2011, 47 10425.

[28] B. J. Lynch, P. L. Fast, M. Harris, D. G. Truhlar, J. Phys. Chem. A 2000, 104, 4811

[29] a) C. Olivier, F. Sauvage, L. Ducasse, F. Castet, M. Grätzel, T. Toupance, ChemSusChem 2011, 4, 731 736; b) S. De Sousa, C. Olivier, L. Ducasse G. Le Bourdon, L. Hirch, T. Toupance, ChemSusChem 2013, 6, 993996.

[30] J. D. Chai, M. Head Gordon, Phys. Chem. Chem. Phys. 2008, 10, 6615.

[31] a) M. Cossi, G. Scalmani, N. Rega, V. Barone, J. Chem. Phys. 2002, 117, 43; b) M. T. Cancès, B. Mennucci, J. Tomasi, J. Chem. Phys. 1997, 107, 3032.

[32] Gaussian 09 (Revision A.02), M. J. Frisch et al., GAUSSIAN, Inc., Walling ford CT, 2009.

[33] a) C. M. Cardona, W. Li, A. E. Kaifer, D. Stockdale, G. C. Bazan Adv. Mater. 2011，23, 2367 2371; b) N. G. Connelly, W. E. Geiger, Chem. Rev. 1996, 96,877910 . 